OF RESILENCE AND EMPOWERMENT: A SINGLE CASE STUDY EXPLORING THE MENTAL HEALTH OF A JEWISH WOMAN WHO IMMIGRATED TO CANADA AS AN INDEPENDENT APPLICANT

\author{
by \\ Melissa Feldman \\ Bachelor of Arts, McGill University, 1994 \\ An MRP \\ presented to Ryerson University \\ In partial fulfillment of the \\ Requirements for the degree of \\ Master of Arts \\ in the program of \\ Immigration and Settlement Studies
}

Toronto, Ontario, Canada, 2017

(C) Melissa Feldman 2017 


\section{AUTHOR'S DECLARATION FOR ELECTRONIC SUBMISSION OF A MAJOR RESEARCH PAPER (MRP):}

I hereby declare that I am the sole author of this Major Research Paper. This is a true copy of the MRP, including any required final revisions.

I authorize Ryerson University to lend this MRP to other institutions or individuals for the purpose of scholarly research.

I further authorize Ryerson University to reproduce this MRP by photocopying or by other means, in total or in part, at the request of other institutions or individuals for the purpose of scholarly research.

I understand that my MRP may be made electronically available to the public.

Melissa Feldman 


\title{
OF RESILENCE AND EMPOWERMENT: A SINGLE CASE STUDY EXPLORING THE MENTAL HEALTH OF A JEWISH WOMAN WHO IMMIGRATED TO CANADA AS AN INDEPENDENT APPLICANT
}

\author{
(C) Melissa Feldman, 2017 \\ Master of Arts \\ Immigration and Settlement Studies \\ Ryerson University
}

\begin{abstract}
This was a single case study, which explored the mental health issues affecting a Jewish woman who immigrated to Canada as a principal applicant. The study looked at the coping strategies "Cecile," a 69-year-old participant who emigrated from Czechoslovakia in 1986, used during her integration vs. settlement process. There were three semi-structured interviews.

The theory of intersectionality was used to examine the intersecting impact of social identities such as racialized status, ethnicity, gender and class have on the participant's mental health. Cecile provided insight into the resilience of Jewish immigrant women.

The social identities Cecile identified with were Judaism, professional status, citizenship, country of origin and immigrant status. The results also show that Cecile displayed resilience in overcoming obstacles. Further research is needed to understand whether other women who have immigrated as independent applicants, Jewish or not, share this resilience.
\end{abstract}

Key Words: Case Study, Mental Health, Resilience, Intersectionality, Coping Strategies 


\section{Acknowledgements}

First and foremost, I would like to thank my supervisor, Dr. Sepali Guruge, for guiding me along this journey with her brilliant insight.

Second, great thanks to my second reader, Corinne Hart, for her wise and thoughtful suggestions.

I would like to express my appreciation for the time, honesty and openness that 'Cecile' brought to the research process.

I would like to thank my parents and my close friends for their love and support.

Finally, I want to express my appreciation for the amazing Immigration and Settlement Studies Class of 2017. 


\section{TABLE OF CONTENTS}

\section{AUTHOR'S DECLARATION FOR ELECTRONIC SUBMISSION OF A MAJOR RESEARCH PAPER}

(MRP)

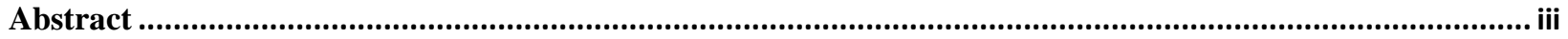

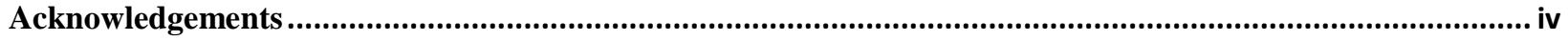

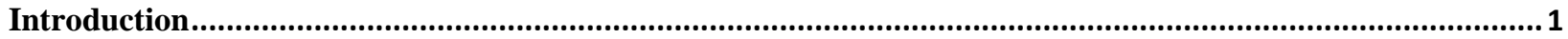

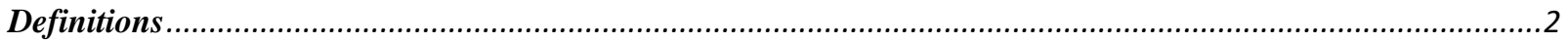

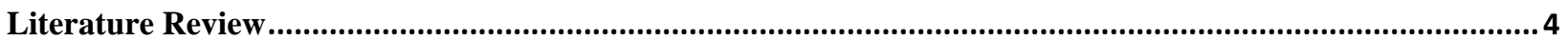

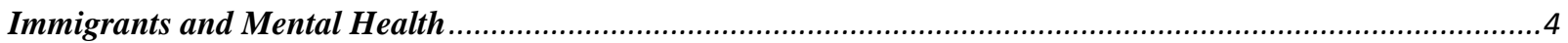

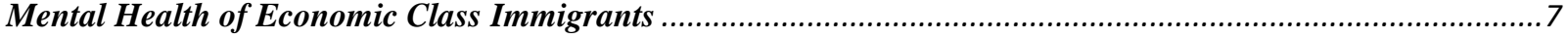

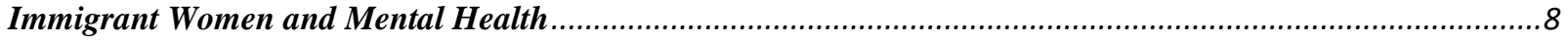

The Canadian and Toronto Jewish Communities ...................................................................................

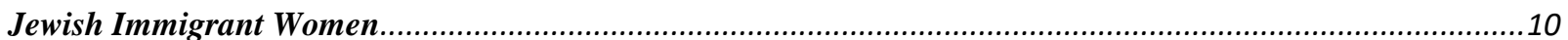

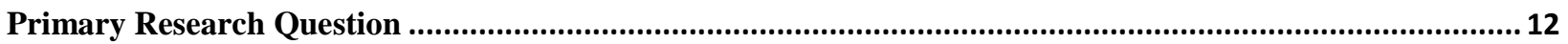

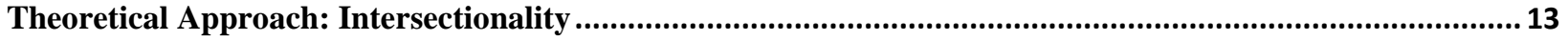

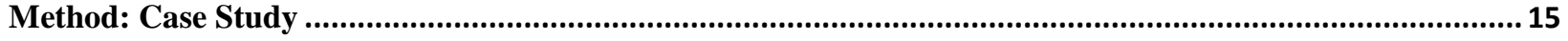

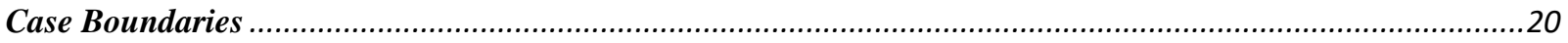

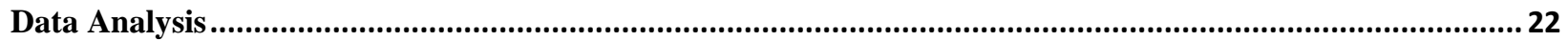

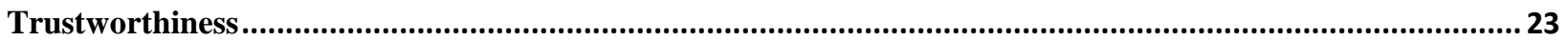

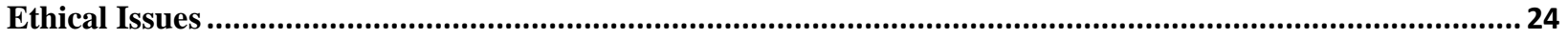

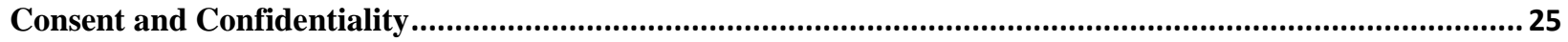

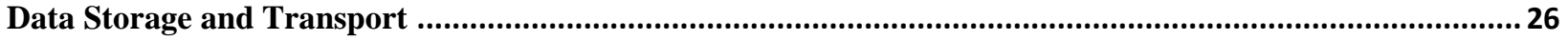

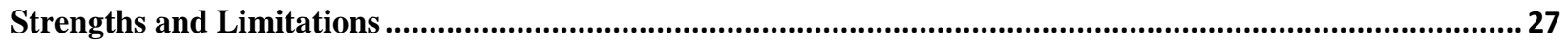

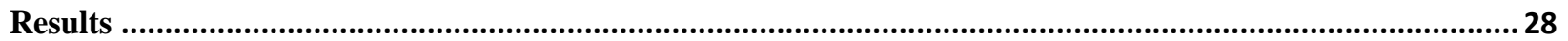

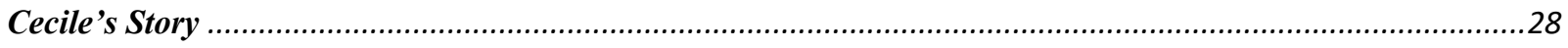

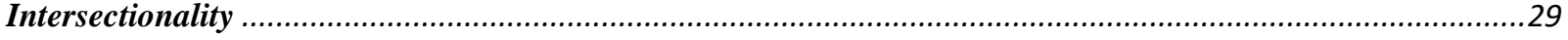

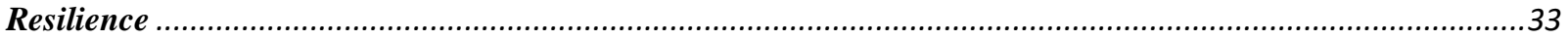

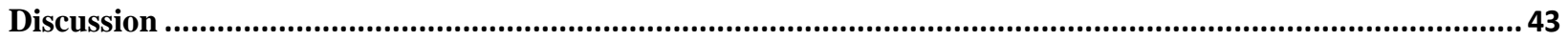




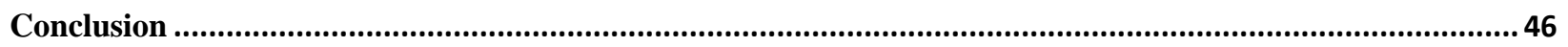

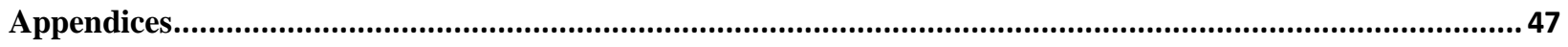

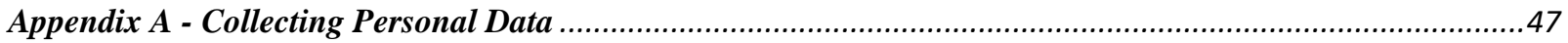

Appendix B - Interview Guide: Researching the Mental Health of a Jewish Immigrant Woman ...................48

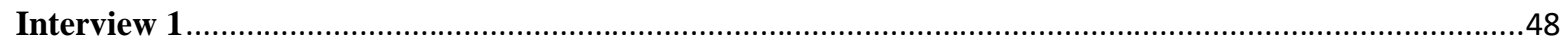

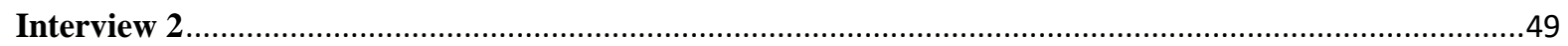

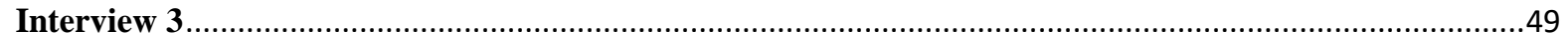

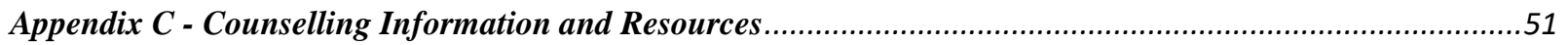

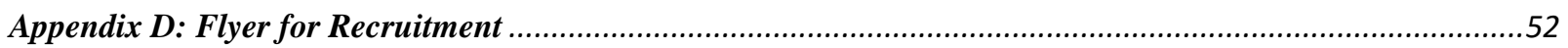

Appendix E: Phone/in person Scripts for Recruitment of Jewish Woman............................................5

Appendix F: Email Script for Recruitment of Jewish Woman ........................................................5

Appendix G: Checklist to Improve Trustworthiness of a Case Study Report ...........................................55

Appendix H: Consent Form for Jewish Immigrant Woman ..................................................................56

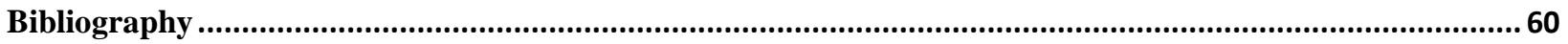




\section{Introduction}

Currently, $19 \%$ of all women admitted to Canada are immigrating independently. This means that they were not admitted through the Family Class (29\% of women) or as the spouse or dependent of a male principal applicant (39\% of women) (Statistics Canada). Under the current system, when a heterosexual married couple immigrates to Canada, the man tends to apply as the principal applicant under the economic class, and the woman is assigned dependent status. Although women are allowed to apply as principal applicants, having the man apply is the usual practice even if the couple has the same level of education and earning potential (Guruge, Collins, and Bender, 2010, p. 117). According to Banerjee and Phan, "In most cases, the women are designated as the dependent applicant during the immigration process because they have lower levels of the human capital that is valued for Canadian immigration" (2015, p. 333). The number of women immigrating independently through the economic class has been steadily rising over time (Guruge, Collins, and Bender, 2010, p. 114).

Most of the literature on the mental health of immigrant women in Canada examines the mental health concerns of immigrant women in the context of family, and often in terms of their role as wives and mothers (Stewart, Gagnon, Merry, 2012; Khanlou, Haque, Sheehan, Jones, 2015; Ballantyne, Benzies, Trute, 2013). Stewart, et al, (2012) for example, examined the risk factors and health profiles of recent immigrant women who have suffered pregnancy-related violence.

The literature often focuses on issues such as postpartum depression (Guruge et al, 2015; Khanlou, Haque, Mustafa, Vazquez, Mantini, Weiss, 2017; O’Mahony, Donnelly, Truong; Bouchal, Este, 2013; O’Mahony and Donnelly, 2013; Vigod, Hussain-Shamsy, Fung, Sultan, Dennis, 2016). For example, Vigod, et al (2016) looked at postpartum mothers in Ontario 
and concluded that the fact that these women underuse postpartum mental health services may be causing the high instance of postpartum mental disorders among immigrant women. O'Mahony, Donnelly \& Bouchal (2013) interviewed immigrant women to assess which factors led them to seek out medical help for postpartum depression, and which strategies might contribute to its prevention and treatment. The researcher in the present study did not find any published studies that have looked specifically at women immigrating to Canada independently, in terms of their pre and post-migration mental health and the factors affecting them.

Certain immigrant communities in Canada, such as the Chinese community, have been the focus of some research in terms of their mental health concerns (See for e.g. Na, Ryder, \& Kirmayer, 2016; Chen, Kazanjian, \& Wong, 2008; Tieu \& Konnert, 2014). Other communities such as the Jewish community, have garnished less attention. This study focused on the mental health issues of a Jewish immigrant woman. The researcher decided to focus on the Jewish community because no research had looked at the mental health issues of Jewish women specifically, with the exception of a $2012 \mathrm{PhD}$ dissertation by A.J. Cohen, which analysed the leadership, power and resilience of Jewish immigrant women in the U.S. during the progressive era through an extensive review of the historical literature.

This MRP takes a single case study approach to understanding the mental health experiences of a Jewish woman who immigrated to Canada as an independent applicant.

\section{Definitions}

In this study, immigrant was defined as a person who moves to a country from any other country with the express goal of residing there permanently (Collins Dictionary, 2016). The World Health Organization defines mental health as, "a state of wellbeing in which the 
individual realises his or her own abilities, can cope with the normal stresses of life, can work productively and fruitfully, and is able to make a contribution to his or her community" (WHO ${ }^{1}$, 2007). The Centre for Disease Control (2016) defines mental illness as, "disorders generally characterized by dysregulation of mood, thought, and/or behaviour," as recognised by the Diagnostic and Statistical Manual, 5th edition, of the American Psychiatric Association.

${ }^{1}$ Retrieved from: http://www.who.int/features/factfiles/mental_health/en/ 


\section{Literature Review}

The literature reviewed for this MRP will be presented in the following order:

1. Immigrants and Mental Health

2. Mental Health of Economic Class Immigrants

3. Immigrant Women and Mental Health

4. The Canadian and Toronto Jewish Communities

5. Jewish Immigrant Women in Canada

\section{Immigrants and Mental Health}

Studies of immigrants in Canada have highlighted that there is a "healthy immigrant effect" for mental health, just as there is for physical health. When they first arrive in the country, immigrants have an advantage over Canadians in that they have better overall mental health (Thompson, Chaze, George, \& Guruge, 2015). Over time, however, these differences decrease and immigrant mental health drops to the country average, or below (Thompson et al, 2015).

In the literature, the immigration process is generally divided into three distinct stages: pre-migration, migration and post-migration. Each stage brings with it different risk factors for mental health, which, depending on the difficulty of the experiences in each stage, can lead to significant problems in this area (Kirmayer et al, 2011). In the pre-migration stage, while planning for the impending move, immigrants with a high level of economic, educational, and occupational status are least likely to experience mental health problems because they generally feel more secure about the future (Kirmayer et al, 2011). Other issues that may negatively influence mental health at this time are related to the stresses of the impending disruption in social network and support (Kirmayer et al, 2011). 
During the migration period, when immigrants are en route to their new homeland, the likelihood of developing mental health problems depends on the conditions of migration. Some may spend time in other countries on the way to the final destination. The primary factors affecting immigrants during their migration are likely to be concerns about the future of their integration into the new society (Kirmayer et al, 2011). In addition, separating from friends, family and the familiar, and going into the unknown, may cause mental health issues during this period. Some groups of immigrants have been shown to have a high rate of psychotic disorders upon arrival (Kirmayer et al, 2011).

After arrival, immigrants' mental health depends on the specific post-migration context for each individual. In general, there are complex post-migration factors influencing the mental health of immigrants, for example, difficulty finding employment, language and cultural differences, loss of status, dealing psychologically with past trauma, barriers to accessing services, lack of a social network, and difficulty getting degrees accredited (Khanloo, 2010). These factors increase the likelihood that immigrant women will develop depression (Guruge and Collins, 2008). In 2008, a meta-analysis carried out by Cantor-Graae and Shelten found that there was a high risk of developing schizophrenia among first generation immigrants, and an even higher risk among the second generation.

In a review of the literature, Kirmayer et al. found that, "Specific challenges in migrant mental health include communication difficulties because of language and cultural differences; the effect of cultural shaping of symptoms and illness behaviour on diagnosis, coping and treatment; differences in family structure and process affecting adaptation; acculturation and intergenerational conflict; and aspects of acceptance by the receiving society that affect employment, social status and integration" (2011). The Longitudinal Survey of Immigrants in 
Canadian statistics state that 29\% of immigrants admit to having emotional difficulties, and $16 \%$ report that their stress levels are very high (Robert and Gilkson, 2012). One of the primary factors influencing immigrant adjustment is a drop in socio-economic status following immigration (George, Thompson, Chaze, \& Guruge, 2015). As would be expected, immigrants are one of the key groups affected by poverty in this country (George et al, 2015). Discrimination and racism can also have a powerful impact on the adjustment process, also leading to possible mental health problems (Thompson et al, 2015).

The amount of social support immigrants have and develop after migration are major factors influencing their long-term mental health. Guruge, Thompson, Usha, \& Chase, (2015) conducted a review of the literature on the role of social support and conflict in women's mental health over a 24-year period. The study concluded that for immigrant women, social support often mitigates the negative psychological effects of the integration process. In contrast, a lack of social support can lead to mental health problems (Guruge et al, 2015). The role of community support and interaction in mediating the development of mental health problems was also stressed by Lai and Hynie (2010) who focused on the role of social exclusion and social isolation on immigrants who are at risk for poor mental health.

$\mathrm{Ng}$ and Omariba (2010) analysed a series of recent studies looking at the factors influencing immigrant mental health, at individual, intermediate and systemic levels. Individual factors include age, gender, cultural heritage, and religious affiliation; intermediate level factors were family, level of social support, and acculturation; and systemic factors were economic barriers, prejudice, discrimination and racism, appropriate services, and access to health care services based on migration status (Khanloo, 2009). 


\section{Mental Health of Economic Class Immigrants}

Economic class immigrants face particular problems in the labour market that can make them

vulnerable to mental health problems (Dean \& Wilson, 2009). Immigrants face many barriers to labour integration in Canada, and one of the most significant problems is the demand in most professions for Canadian work experience and the non-recognition or devaluation of professional degrees, work experience, and credentials from many other countries (Girard \& Bauder, 2007, p. 35). The professional labour bodies present many deterrents, including length of time to process applications and strict rules for transfer of qualifications (Gabriel, 2006, p. 173). These issues stem largely from the belief that credentials and education, particularly from developing countries, do not meet Canadian standards (Guo, 2009). Even the immigrants who do manage to get their credentials recognised are not guaranteed a job in their profession, and may endure discrimination, labour shortages, and other difficulties (Guo, 2009). According to Guo (2009), "the inaccessibility to professional occupation for which current immigrants have prior learning and work experience leads to downward social mobility, unemployment and underemployment, vulnerability and commodification, and reduced earnings" (p. 42). The low earnings of immigrants compared to Canadian born people are well known, and are directly linked to the problem of non-recognition of credentials and past work experience (Guo, 2009). Many researchers believe that these problems are directly linked to racism from the professional labour bodies and the Canadian labour force (Guo, 2009). The situation for immigrant women is even direr when it comes to employment discrimination and racism. (Guo, 2009). 


\section{Immigrant Women and Mental Health}

Research indicates that in Canada, immigrants in general use fewer mental health services than those who are Canadian born - particularly immigrant women (Kirmayer et al, 2011). They are also less likely to be referred to mental health services (Guruge et al, 2010; Kirmayer et al, 2011). This is particularly true of women who are not aware of the available services, have no means of getting information about them, have transportation or mobility issues, or the service providers lack translation services (Guruge et al, 2015, p. 664).

The stigma associated with mental illness may be more pronounced in some communities. Stigma may prevent many immigrant women from seeking help (Guruge et al, 2015). In Chinese communities, for example, the stigma against mental illness is quite powerful (Yang et al, 2011). It's not uncommon for people in this community to delay or avoid seeking treatment for a mental health problem (Yang et al, 2011). South Asian communities in general tend to hold a powerful taboo about sharing private information outside the family. This is a huge barrier to women seeking out mental health services (Thompson et al, 2015). Racialized immigrant women in particular are known to have very low rates of mental health service usage, largely due to systemic discrimination (Thompson, 2015). Other key barriers affecting mental health service usage for immigrant women include lack of access to culturally or linguistically suitable services, difficulty getting information about health services, and settlement issues such as discrimination and lack of social support (Thompson, 2015).

There are many issues that influence the mental health of immigrant women who have immigrated to Canada independently. Lack of social support is one of the key factors (Guruge et al, 2015). Immigrant women often have less social support than Canadian women because they live far away from friends and family in their home countries (Guruge et al, 2015). Other factors 
affecting mental health include possibly having to take a job they are overqualified for, or an inadequate salary, which could lead to financial problems. Studies have indicated that immigrant women are considerably poorer than Canadian-born women and men, and also poorer than immigrant men (Guruge, Collins \& Bender, 2010).

\section{The Canadian and Toronto Jewish Communities}

The current Canadian Jewish community is quite large, with about 391,665 people. The majority of Jewish people in Canada live in the province of Ontario, and the majority of the Jews in Ontario live in Toronto $(188,710)$, which is the biggest Jewish community in the country (The Centre for Israel and Jewish Affairs, 2011²).

Jews have been immigrating to Canada since 1760. Jewish immigrants from England and British North America ${ }^{3}$ established the first organised Jewish community in the city of Montreal at that time (Robinson, 2009). Jewish immigration took place slowly, over time. In the $19^{\text {th }}$ century some Jews immigrated from England and Central and Western Europe. By 1870, the Jewish community in Canada was made up of 1000 people, most of whom lived in Quebec or Ontario (Schnoor, 2011, p. 180). The community continued to grow and by the start of the $20^{\text {th }}$ century, Jewish communities were spread all over Canada. At that time, a mass immigration of Eastern European Jews from Russia, Poland and Romania was underway (Robinson, 2011). The community became even more diverse in the 1950s, when a big group of Sephardic Jews from North Africa immigrated and settled in Quebec. In addition, 4,000 Hungarian Jews fleeing the uprising settled in Toronto (Schnoor, 2011). In the 1970s and 1980s and onward, Jewish

\footnotetext{
${ }^{2}$ Retrieved from http://www.cija.ca/resource/canadian-jewry/basic-demographics-of-the-canadian-jewishcommunity/\#

${ }^{3}$ The former name for Canada in the British Empire (Collins Dictionary)
} 
immigrants from Russia, South Africa, Israel, Ethiopia, India, Latin America, and the United States arrived and added to the multicultural aspect of the Jewish community in Canada (Schnoor, 2011).

The history of Jewish immigration to Canada has indicated, according to Schnoor (2011) that Jews, "have been successful in integrating into larger Canadian society, while at the same time retaining a vibrant internal Jewish religion and culture (p. 179)." As stated previously, the established Jewish community is somewhat culturally distinct from the Israeli Jewish community. Doenyas (2016, iii) describes this phenomena and compares it with the United States:

This data reveals what seems to be a trend of Israeli assimilation into the American Jewish community and the general American society, while in Canada, the Israeli community ostensibly remains distinct from the local Jewish community and the general Canadian society (Doenyas, 2016).

There has traditionally been a stigma associated with Israelis living abroad, and many Israeli immigrants have felt guilty about 'abandoning' the country. This relates back to the concept in Judaism that all Jews should return to Israel, the homeland. Moving to Israel is considered a highly spiritual and positive act, while moving away is considered highly disloyal to the country. However, Harris $(2015$, p. 45) has noted that the stigma has lessened considerably in recent times and that only a few of the Israeli immigrants she interviewed in her Vancouver study felt such guilt.

\section{Jewish Immigrant Women}

Much of the literature on Jewish immigrants in North America, and the experience of Jewish immigrant women, is based on the Jewish immigrant experience in the United States (Koffman \& Weinfeld, 2011, p. 201) However, unique factors have shaped the Canadian Jewish 
communities. Research has looked at several of the Canadian Jewish immigrant communities that exist (Koffman \& Weinfeld, 2011, p. 209). These communities are composed of uniquely Canadian elements and influenced by uniquely Canadian issues, such as the conflict between the French and the English. Particularly in Quebec, this issue is a focus in studies of Jewish life, because it impacts Jewish life (Koffman \& Weinfeld, 2011). Starting in the 1970s and 1980s, a wave of Sephardic Jews from North Africa settled in Quebec. Drawn by the French language, they integrated into Quebec society. Starting after the Second World War, thousands of Holocaust survivors and other Eastern European immigrants streamed into the country, and in the decades following Jews from Hungary, Iraq, Egypt, Soviet Union and South Africa settled in Canada and made Jewish life very multicultural. Other Canadian features that have an impact on Jewish life include immigration policies, geography and its British influence (Koffman \& Weinfeld, 2011). There still continues to be much Jewish immigration to Canada, making the 2011 rate of foreign-born Jews 25\% (Koffman \& Weinfeld, 2011, p. 209).

From the end of the $19^{\text {th }}$ century until about the mid-20s, there was a mass immigration of Jews from Eastern Europe flowing into North America (Hyman, 1991). More Jewish women immigrated at this time than women in any other ethnic group (Hyman, 2009). Hyman (2009) cited that among the Jews who immigrated to the United States between 1886 and 1914, 44\% were women (Hyman, 1991). Most Jewish immigrants came from an urban, capitalist society where women had skills and experience in the marketplace; perhaps more than some of the other groups of immigrant women (Hyman, 1991). Hyman has explained that, "women worked alongside men, supporting their families primarily through petty commerce, selling all kinds of produce in the marketplace, and also through artisan trades, such as, shoemaking and tailoring. In 
the small number of traditional families where husbands devoted themselves to studying Torah, women bore the major responsibility as breadwinners for their families" (Hyman $\left.{ }^{4}, 2009\right)$.

On average, Jewish immigrant men in North America did well in the labour market around the turn of the $20^{\text {th }}$ century. This allowed the women to be full time housewives and mothers if they wished. However, many Jewish women sought work outside of the home, and research indicates that many women reported that they felt free and in charge of their own lives (Hyman, 2009). Many Jewish working women became politically active and involved in trade union activism, participating in strikes and picket lines (Hyman, 2009).

Being from a different region with a separate history, Israeli immigrant women are influenced by different cultural factors than the Eastern European Jewish women. The political turmoil and conflict that is part of Israeli life have influenced Israeli women in particular ways, especially since they participate in the Israeli army alongside Israeli men.

Until the present moment, there have been no studies looking at the mental health of Jewish immigrant women in Canada. In particular, Jewish women who immigrated to Canada independently through the economic class are overlooked in the literature.

\section{Primary Research Question}

What are the issues influencing the mental health of a Jewish woman who immigrated to Canada as an independent applicant, and how did she cope with these issues?

\footnotetext{
${ }^{4}$ Retrieved from https://jwa.org/encyclopedia/article/eastern-european-immigrants-in-united-states
} 


\section{Theoretical Approach: Intersectionality}

This study examined the participant through the lens of intersectionality. The intersectionality approach looks at the way social categories like class, race and gender influence a person's life experiences, including their experience of inequality, and how they can create, "interlocking systems of oppression" (Greene, Evans, \& Subramanian, 2017, p. 214). According to this approach, looking at only one of these social categories is meaningless, because women's experiences are molded by all of them in combination and in context. Racism, sexism, and other similar concepts also operate together to create inequalities (Greene et al 2017). Furthermore, the interconnections of all of these social categories have an influence on health outcomes (ViruellFuentes, Patricia, \& Abdulrahim, 2012). The approach examines the intersecting impact of these factors on women's health, including mental health (Viruell-Fuentes et al, 2012).

Until recently, explanations for immigrant health focused on cultural factors, and largely ignored the possible effects of structural inequalities (Viruell-Fuentes et al, 2012). According to Viruell-Fuentes et al (2012, p. 2099), "a richer understanding of the social determinants of immigrant health requires an intersectional approach.”

In the past few years, there has been some immigrant health and health policy research that used intersectionality as a lens. In 2012, Koehn, Neysmith, Kobayashi, and Khamisa used intersectionality as their theoretical construct to carry out an extensive literature review on the health and health-care access of ethnocultural minority older adults. Yan (2014) Used intersectionality to examine the sexual health needs of racialized LGBTQ youth living in Toronto, Canada , by interviewing service providers. 
The approach takes into account the diversity of women on all levels. The interview participant in this study was not only an immigrant woman or a Jewish immigrant woman, she was also from a certain country, background, socioeconomic and political context. She has experienced prejudice and discrimination as part of her life experiences. The process of data analysis and the discussion took into account how all of these social categories had an impact on her mental health outcomes. 


\section{Method: Case Study}

Originally, this was a qualitative study which aimed to explore the key mental health issues affecting Jewish women who had immigrated to Canada as principal applicants, and the ways in which services and treatment for this population could be improved. It was to be an ethnographic study with ten Jewish immigrant women over the age of 18 , who entered the country as primary applicants through the economic class. The interview guide used was the same as the one used in Cecile's first interview (Appendix B, Interview 1). The data were to be triangulated by carrying out interviews with five mental health professionals who worked with this population.

The researcher drew up a strong recruitment plan with this aim in mind. The recruitment stage of this study was very difficult, and the researcher spent three or four full-time weeks making calls (Script, Appendix D), sending emails (Script, Appendix F), putting up flyers (Flyer, Appendix D) in Jewish neighbourhoods and meeting with employees at Jewish organisations (in person script, Appendix E). The difficulty was not due to people being unhelpful. On the contrary, staff at these organizations were for the most part very willing to help. The Miles Nadal Jewish Community Centre agreed to put up two flyers. The Media and PR Coordinator at the Jewish Russian Community Centre of Ontario agreed to send out the information to the community members. The researcher spoke with one of the two presidents of the National Council of Jewish Women of Canada on the phone for quite a while and she showed real interest in the project. However, none of the research projects they were doing had any connection to immigration, and they did not know any immigrant women who would suit the project requirements. Jewish Vocational Services agreed to put up flyers and to give any woman who fit the project requirements the information for the study. However, even after all of this effort, no immigrant women got in contact to be interviewed. 
The researcher was told by staff at Jewish Immigrant Aid Services that the population being studied here is quite miniscule and it would be very difficult to find the intended sample. There are simply very few Jewish women who immigrate to Canada as independent applicants. In addition, mental health workers who would counsel this population were difficult to access because they work mostly in hospitals. Hospital ethics approval takes considerable time and given the time constraints for an MRP completion, the hospitals were not contacted. Several organizations that do counselling were approached, such as Jewish Family and Child and Circle of Care, but they all stated that they did not work with immigrants. Some agencies, such as Jewish Immigrant Aid Services, have settlement workers but no mental health workers. Clearly there is very little in the way of mental health counselling for Jewish women who immigrated to Canada independently, outside of the hospitals. This may be true of Jewish immigrant women in general.

Another very relevant issue was pointed out by staff at Jewish Immigrant Aid Services. They said that writing that Israelis may not participate in the study was unclear. Russian immigrants who had immigrated to Israel before immigrating to Canada may think that they were excluded, and that would leave out quite a number of people. This was important information, and the researcher edited her flyer so that it said that people who were 'born in Israel' could not participate. However, it was unfortunate that so many flyers had been distributed already with the mistake.

After several weeks, the researcher found one participant to interview who fit the study criteria, through her own personal network. In interviewing the one participant, Cecile, for the first time, it became very clear to the researcher that this participant could be ideal for a single case study of this quite unexplored population. Stake states that, "a case is selected because it is 
interesting in itself or can facilitate the understanding of something else; it is instrumental in providing insight on an issue" (Harrison, 2011 ${ }^{5}$ ). Cecile provided a tremendous amount of insight into the quality of resilience. In light of the difficulty finding research participants and the fact that this was an interesting person, the researcher decided to turn the project into a single case study. In a single case study, the researcher examines only one particular case (Zainal, 2007). The case study is also a good way to begin researching an unknown area or an unknown population (Baxter and Jack, 2008). The mental health of Jewish woman who immigrated to Canada independently is an un-researched area for an un-researched population.

This study aligns with Skate’s (1995) approach. Skate follows a constructivist perspective, which suggests that the way someone views truth and reality depends on that person's individual perspective of constructed reality (Skate, 1995). Constructivism implies that researcher and participant will work closely together, and that the researcher will listen carefully to the participants as they describe how they see reality (Skate, 1995).

In Skate's (1995) approach, one of the key reasons for conducting a case study is because the case itself is intrinsic, meaning that it is of particular interest for the purpose of research and not representative of any group (Crowe, Cresswell, Robertson, Huby, Avery \& Sheikh, 2011). The purpose is specifically to examine some individual or situation that is unique, for the value of the knowledge itself (Baxter \& Jack, 2008). The present study entails an intrinsic look at a unique individual who is a Jewish immigrant women who immigrated to Canada as an independent applicant. The participant was selected because she agreed to be interviewed, and because she could contribute to the understanding of the experience of a Jewish woman who

\footnotetext{
${ }^{5}$ Retrieved from http://www.qualitative-research.net/index.php/fqs/article/view/2655/4079\#g4
} 
immigrated to Canada as an independent applicant. However, during the first interview the information she provided about her own resilience led the researcher to realise that she was unique, and a candidate for an intrinsic study. During the analysis of each transcript, the researcher was able to pinpoint specific personality traits in Cecile's character that have been directly linked to the concept of resilience.

The primary method of data collection in this single case study was semi-structured interviews. After each interview, the researcher also recorded her observations and thoughts about the interview, and any insights regarding tone or body language. These notes were analysed with the rest of the data to get a full picture of the case context. Galletta (2013) explains the benefit of semi-structured interviews in research:

It creates openings for a narrative to unfold, while also including questions informed by theory. It also leaves a space through which you might explore with participants the contextual influences evident in the narratives...(p. 2)

The case study is rigorous enough to be used in health science research. (Baxter and Jack, 2008). Kohn (1997, p. 2) has pointed out that, "the use of case studies as a research methodology has grown in recent years because of the rapid changes in the health system today."

The researcher conducted three semi-structured interviews with Cecile, a 69-year-old Jewish woman from Czechoslovakia who immigrated to Canada in 1986 as a primary applicant through the economic class. It is important to acknowledge that the participant did immigrate to Canada 30 years ago, when Canadian society and the context for immigration were different. This will be taken into account during the analysis.

She was given a $\$ 30$ incentive at the start of each interview, which was the amount allotted in the research budget. She was entitled to keep the money whether she completed the 
interview or not. The interviews were conducted in a private, rented room in the Ryerson University Library. Please see Appendix B for a copy of the interview guide for each of the three meetings.

The researcher's position as a Jewish woman who was previously an immigrant on her own in a strange country during the same age range studied here was helpful in better understanding the context. Having this 'insider' knowledge is useful in this type of study (Bonner \& Tolhurst, 2002). Dr. Sepali Guruge (MRP supervisor), an 'outsider', reviewed the notes and the interview transcripts to pick up on details that were missed by the researcher as the insider (Bonner \& Tolhurst, 2002).

Intersectionality "aims to make visible the multiple positioning that constitutes everyday life and the power relations that are central to it" (Phoenix \& Pattynama, 2006, p.187). Therefore, it is important to analyze the position of the researcher in relation to the participant, the dynamic, and the power relations between them. In this situation, the researcher was a 46year old Jewish woman who was born in Canada and of Eastern European family background. She immigrated to Israel on her own at the age of 26 and remained for 18 years, so she is able to relate to the immigrant experience of a woman immigrating on her own. The fact that researcher and participant were both Jewish and had both gone through an immigration experience seemed to influence the relationship in a positive way. There was a feeling of trust between researcher and participant, and open communication. It is well established that being a cultural 'insider' in a research study increases the likelihood that there will be a feeling of 'intimacy' between researcher and participant. In turn, this may help the participant to be open and speak freely (Bonner \& Tolhurst, 2002, p.9). Being an immigrant woman in the past, the researcher had the expectation of hearing that certain experiences would be difficult and stressful, and the resilience 
of the participant was a surprise. Some of the questions asked in the second interview were trying to get at specific experiences that under the researcher's assumption should be psychologically taxing on a new immigrant, and that were taxing for her during her own immigrant experience. The fact that they were not was of great interest and really drove the 'new' study forward.

There were very few risks involved in participating in this study. However, the topics under discussion involved personal experiences and emotions, so there was always the chance that the participant could have felt uncomfortable. The participant was told that she could stop the interview or withdraw her data at any time, either for a break or completely, including after the interview was over. In addition, the researcher had prepared a list of mental health resources that may have been of use to the participant (Appendix C).

\section{Case Boundaries}

The primary unit of analysis in a case study is the case. A case is a bounded entity of some kind (Baxter \& Jack, 2008). Binding a case is necessary in order to limit the objectives of the study, making sure the research question and study scope does not get too expansive. The researcher must define what the case consists of and what it does not consist of. Case study researchers such as Yin (2003) and Stake (1995) have suggested that case studies have clearly defined boundaries, and "these boundaries also indicate the breadth and the depth of the study and not simply the sample to be included" (Baxter \& Jack, 2008, p. 547).” Cases must be bound by conceptual categories such as time and place, time and activity, or definition and context (Baxter \& Jack, 2008). 
In this study, the case was bound by context and identity. The researcher defined the case as an examination of the mental health of a Jewish immigrant adult professional woman. In this study, Jewish is defined as, an individual with at least one Jewish parent who identifies as being Jewish. The context is that the woman must have immigrated to Canada more than five years ago as an unmarried independent applicant in the economic class. This allows time for immigrants to live here for a long enough period of time to have acquired experiences to discuss. Another condition set for the study is that the participant must speak English fluently enough to understand and be understood in an interview.

On the other end, when defining what the study does not consist of, boundaries are also based on context and identity. The researcher defined the case as not an Israeli married immigrant adult woman, nor a non-Jewish married immigrant adult woman, who immigrated to Canada less than five years ago as an applicant through the family or refugee classes.

Demographic data were collected from the participant (Appendix A) for the purpose of obtaining a deeper analysis and making sure that she met the criteria. This included ethnicity, age now and at the time of immigration, profession, educational level, marital status at the time of immigration, and length of time in Canada. 


\section{Data Analysis}

The data analysis process for this study was as follows:

1) Interviews were transcribed word for word after each meeting, and all of the field notes were used in the analysis.

2) After the first interview, the researcher read through the notes and interview transcripts several times.

3) Preliminary coding was done and some themes and categories were identified.

4) The themes and categories were confirmed in the second and third interviews, and new ones were generated by coding the second and third transcripts.

5) Using the codes, relevant quotes were extracted from the text and arranged under the codes.

6) Patterns were drawn and new themes that seemed significant to the participant were analysed. 


\section{Trustworthiness}

Researchers who use the case study method often receive criticism suggesting that the approach lacks rigour because it does not allow for the transfer of results to contexts outside the research situation (Crowe, 2011). Stake (1995) has suggested that full transparency in all aspects of the research process and reporting of the data greatly improves the trustworthiness of the study. In this study, trustworthiness was assessed using a checklist developed by Stake (Crowe, 2011) which is outlined in Appendix H. The use of this checklist improved the credibility of the study. According to Stake, the interpretation phase of the study should also be completely transparent (Crowe, 2011). Stake has suggested that transparency in interpretation and reporting findings genuinely assists the reader to evaluate the trustworthiness of the case study (Stake, 1995). This is particularly crucial in an intrinsic study like this one, where the researcher is looking at a unique case (Stake, 1995).

This checklist focuses largely on the written report: the presentation and interpretation of the findings. In the present study, the written report of the study findings was very central, and a detailed check that procedures were followed exactly was important. In addition, Dr. Sepali Guruge (MRP supervisor) oversaw the research process.

The study cannot be said to be neutral, due to the similarities between researcher and participant and the fact that the researcher's immigrant experience certainly influenced the questions she asked. The questions were very influenced by the issues that the researcher assumed would most impact on a Jewish immigrant women's mental health. This lack of neutrality made the positionality of the researcher valuable in this study. She had the ability to judge which experiences might be difficult, in a way that someone who hasn't been a Jewish immigrant woman - someone neutral - could not. 


\section{Ethical Issues}

In this study, the ethical issues related to protecting the confidentiality of the research participants fairly and ethically according to the Ryerson University Policy of Senate; Ethical Conduct for Research Involving Human Participants. This includes respect for persons and concern for welfare and justice. Refer to the appendices for the documents submitted. This research project was approved by Ryerson University's Research Ethics Board REB 2017-138. A few weeks later, REB approval was sought again to contact the participant for a $2^{\text {nd }}$ and $3^{\text {rd }}$ interview. The participant had already approved being contacted for follow-up interviews. The request was approved by Ryerson University's Research Ethics Board REB 2017-138. 


\section{Consent and Confidentiality}

The interview participant was given a consent form (Appendix $H$ ) to sign, which explained the details and purpose of the study in clear, simple and direct language and with full disclosure. Participation in the study was voluntary, and this was stated clearly on the form. The signing of the consent form occurred before the interview took place. It was sent to the participant a day in advance, so that she could read it on her own and have a chance to change her mind about participating in the study when she was not face to face with the researcher.

When researcher and participant met in person, the researcher went over the form verbally and reminded the participant again of her chance to withdraw at any time during the interview process. This included withdrawing her data at any time after the interview. The consent form included information about the purpose of the study, what would take place, the potential risks and benefits, a description of the confidentiality agreement, and how participants might withdraw from the study if she chose to do so.

All personal identifiers were removed from the transcriptions and no personal identifiers were used in reporting the results of the study. Pseudonyms were used for the participant and anyone she mentioned in the interview. 


\section{Data Storage and Transport}

No data were transported or sent electronically. The recorder that contained the audio recordings was taken by the researcher from the interview location to the researcher's home directly after each meeting. The recordings were stored in the researcher's computer, which was locked with a password until the completion of this report (MRP), at which time they were deleted. The transcripts with no identifying information will be kept locked in Sepali Guruge's (MRP supervisor) office for five years, in case a follow-up study is done. 


\section{Strengths and Limitations}

The mental health of Jewish immigrant women in Canada, particularly those who are primary applicants, is an un-researched area. As such, this study made an important beginning contribution to the existing body of research on immigration and mental health, by shining some light on the issue of resilience. It must be acknowledged, however, that the participant in this study immigrated to Canada in 1986, when the context for immigration was different. It's also true that although experiences and the world change, resilience does not. The major challenges immigrants experience are still very similar, in terms of economic barriers, financial constraints, social isolation, and other risk factors. In fact, the immigrant experience in Canada in the 80s would have been more difficult than at the present time, because the country was experiencing a major recession (Kelley \& Trebilcock, 2010). However, the quality or coping strategy of resilience, a positive mental health response to these risks, it just as relevant today as it was 30 years ago.

A big strength of this study is that the researcher is an insider in the community of focus, and was able to make insider observations and come to conclusions about them based on this knowledge. This familiarity may have made it more likely that the participant would have been more open to engage in an in-depth interview (Bonner \& Tolhurst, 2002).

The weakness of being an insider in this type of study is that overfamiliarity with certain behaviour patterns that may lead the researcher to miss routine information (Bonner \& Tolhurst, 2002). In this situation, while the researcher is an insider in the community, she also lived abroad for 18 years in Israel. The culture in Israel is quite distinct from the culture of the Toronto Jewish community, and this distance may have allowed the researcher some objectivity. 


\section{Results}

\section{Cecile's Story}

All three interviews with Cecile took place in a small private room in the Ryerson library. Her English is at about an intermediate level: she can converse fluently, but often lacks grammatical accuracy. Preliminary data analysis conducted after the first interview strongly indicated a genuine resilience in the face of difficulties that have overwhelmed many immigrants.

Cecile was single, 40 years old, and a pharmacist when she immigrated to Canada in 1986, after having defected from Czechoslovakia to Germany. Her parents had already passed away, and her sister was in Canada with her family. She described the moment, while visiting family in Toronto, that she made this decision:

And then, it all of the sudden hit me that I have nobody there...no family in Czechoslovakia. So I came back home, and I said wait, what am I going to do here? So I bought a ticket...not a ticket ...but a trip to West....Germany, Switzerland, Austria.

In Germany, Cecile explained that she stayed with a distant cousin for five weeks, who contacted his lawyer about her immigration to Canada. The lawyer advised her to leave Germany and travel to Austria, where there was a branch of HIAS (Hebrew Immigrant Aid Society). She said that she waited in Austria for 6 months, working under the table and taking a 12-week English course given by HIAS, until her paperwork was done and she could travel to Canada as a permanent resident.

Once in Toronto, Cecile said that she took up temporary residence with her sister and her family in the suburbs. She stayed there for eight months, taking care of her nephew, until she found an apartment with a roommate and her first Canadian job as a salesperson in a bakery for minimum wage. She described how after just a few months, the apartment was robbed and some 
of her jewellery and other valuables were stolen. Some of these were sentimental items of value. She explained what happened when the police arrived:

And the police officer screamed, and one was actually asking (both immigrants), "Don't you hate that you moved to Canada?" and I said like, "No. I do not. The same thing could happen back home.

She did not yet have the language skills to do her pharmacy re-licensing exams, and she was not sure whether she wanted to go back to pharmacy at the time. She reported obtaining her license seven years later, at the encouragement of a friend from back home. Cecile said:

She passed all the exams, and she was doing time for the internship and so on. And she goes okay, like what do you want to do, work all your life for five bucks an hour? Think about it, you have your education, you are a pharmacist, and you were a pharmacist for many years back home, you are certainly smarter than most of them here, yeah?

Cecile's battle to find a pharmacy that was not asking for Canadian Experience was very challenging, but she said that eventually she did find work and quickly went from delivery person to assistant to manager at the pharmacy that employed her. Cecile retired at the age of 65 , and at the time of the interview was living in Thornhill, Toronto.

\section{Intersectionality}

Intersectionality approaches postulate that experiences are molded by all of the social categories that pertain to an individual, such as gender, race, and class (Viruell-Fuentes et al, 2012). "These systems of oppression are mutually constituted and work together to produce inequality" (Viruell-Fuentes et al, 2012, p. 2100).

Analysis of all three transcripts revealed that the social categories of gender and sexual identity have very little impact on Cecile or her mental health; certainly in her perspective. She did imply in one statement that she was heterosexual but never having been in a relationship. The participant explained her perspective on relationships: 
I was never married; I was never in relationship, basically, so... I don't know if the relationship will do things more difficult...because, I don't know, I got a job and he didn't, and now he will be like, "I don't know what to do, let's go back home.

In terms of gender, even when asked directly if being a woman had an impact on her immigration in any way, she simply thought about it and then indicated that there hadn't been any gender-related issues. However, the quote above does indicate that she sees the benefits of being a single woman, which could have a positive effect on her mental health. She didn't recall ever having been discriminated against specifically because she was a woman, on an individual level. The reasons behind the fact that gender isn't an issue at all for Cecile are not completely clear, and they may be quite individual. However, there was no indication at all that she was being deceptive. Cecile maintained a confident, relaxed pose for the majority of the interviews. She was very open, questions regarding gender did not make her uncomfortable, and we had a trusting and comfortable rapport. Since gender is the central principle of feminism, this is an unusual finding to discuss using a feminist theory. However, it's fair to assume that gender simply is not an aspect of her identity that she sees as oppressive.

The social categories that resonate the most powerfully with Cecile are Judaism, professional status, immigrant status, country of origin, and citizenship. Cecile associates Judaism with friendship, and with receiving help, which are factors that would almost certainly have a positive impact on her mental health. She identifies as being quite secular, and never goes to synagogue, stating that, "until today I'm not a member..." When asked about her religious affiliation, she responded indicating her affiliations with other Jews, not with religion, explaining that, for example, "I have those friends that I know for 20 years now...more than 20 years, $22 \ldots$ a Lubavitch family, but they are Canadian.” 
Cecile strongly associates Judaism with receiving help, and she sees Jews and the Jewish community as a safe haven. This became clear when she was discussing her immigration process from Austria to Canada. She explained that, "The lawyer of my cousin, he connected us with HIAS (Hebrew Immigrant Aid Society). It is an organization that helps the Jewish people to immigrate. They took my passport and took all the information and did all the paperwork for immigrating to Canada. You know, like my sister, contacted my sister who contacted some people, if anybody knows me ...you know. If I am really Jewish, because they were helping only Jewish people." One point to acknowledge is that as a Jew, although she may be at risk for antiSemitism, Cecile is visually white. That in itself lessens her chances of being discriminated against and makes her immigration easier than for a racialized woman.

After Cecile was re-licensed as a pharmacist, she had a lot of trouble getting a job due to her lack of 'Canadian experience'. She decided to approach the Registrar at the Ontario College of Pharmacists directly, and set a meeting with him. She remembers vividly how he responded when at one point during their discussion, she mentioned that she was Jewish:

And he was like, "You are Jewish? You know, I wanted to help you, but now I have to help you." So he gave me like, 10 or 12 or I don't know how many names, and pharmacies, and telephone numbers, of the people, and he said like, "Just tell them I sent you."

According to Cecile, In Czechoslovakia, the profession of pharmacist is very highly regarded in the society, on par with a medical doctor. The pharmacy itself has its own premises and sells only medications, not toiletries or other items. Cecile explained that, "The pharmacy was like a little god, second to doctors." She found the system here, and the level of status of the profession, quite different than what she was used to. She initially decided that she would rather work at a job far below her level of education and abilities, taking a huge drop in social status, 
than become a pharmacist with less social status than she had had in the past. She said that, "first I thought I will never go back to the pharmacy, because I just didn't like that setting that is a post office, that is all the eh....toothpaste and...you know. I thought, at that time I thought the pharmacist is selling....how you call ...the stamps and you know...like...I just didn't like it because back home ...the pharmacy is a separate entity."

Cecile certainly identifies as an immigrant - as someone from elsewhere - and in many ways this 'othering' of herself is a part of her identity that she is very proud of. When talking about what she missed from 'back home,' at one point she made a comparison between the architecture in Europe with that of Canada. Europe was used as a sort of status symbol. She articulated that, "I missed...the fact that when you're in Europe and something is historical it's like hundreds and hundreds or years old, yeah? Not like this, something 20 years old and they say it's historical, yeah? (laughter) It's hysterical. (laughter) They're no more than 150 years old here."

It is in examining the approach that Cecile takes to discrimination that her resilience begins to reveal itself. In a job interview for a pharmacy position, Cecile explained how she defended herself against the interviewer's poor treatment using her 'status' as a Canadian and as a person from Europe:

With one guy I really had a touchdown, and (laughter) he goes like, "Why should I hire you instead of a Canadian student?" And I said like - I looked at him and I said, "Sir, if you don't mind, I'm Canadian too. In terms of citizenship...aaanddd the difference between me and so-called Canadian student is that, yes you have to teach me computer and you have to teach me something about the practice, but, I think I know my pharmacology because I have 15 years' experience from Europe. IF you know where Europe is." And then I slammed the door in his face! 
In trying to answer the research question set out in this study, it became clear to the researcher that this participant did not have a lot of mental health issues. In addition, unlike what the researcher would have predicted, Cecile did not seem to have experienced much in the way of negative mental health symptoms in relation to her immigration experience. This led to the concept of resilience as a lens through which to view Cecile and her mental health.

\section{Resilience}

Looking at Cecile's pre-migration and migration experience, there was a lot of uncertainty and extreme stress involved that could have led to mental health problems. Similarly, living in the suburbs, being socially isolated and not speaking the language is also a very difficult situation. Cecile experienced many of the stressors specific to immigrants, and she was still mentally healthy. She experienced unemployment, underemployment, low salary, a huge drop in professional status, robbery, and other difficulties, and she always found coping strategies to deal with each circumstance. The 'healthy immigrant effect' common to many immigrants, where their mental and physical health get worse over time, does not apply to Cecile. Her mental health started out high, and it remained that way. She has a tremendous amount of resilience.

Resilience is, "the capability of individuals to cope successfully in the face of significant change, adversity, or risk. This capability changes over time and is enhanced by protective factors in the individual and the environment" (Stewart, Reid \& Mangham, 1997). Protective factors, for example, may include social support (Toth, 2003). Toth (2003) has stated that a resilient person "has a sense of meaning and purpose in their life."

One of the most fascinating findings of this study was Cecile's tremendous resilience in the face of difficulties that are generally very challenging for immigrants to endure. Research has 
generally found that, "the social determinants of health such as social exclusion, racism, unemployment, and poverty have been linked to immigrant women's well-being" (MacDonnell et al, 2012, p.2). Cecile experienced all of these factors during her early immigration, and still she thrived mental-health wise. Since these barriers often lead to poor mental health in immigrants (Khanloo, 2010), it's worthwhile to examine Cecile's personal qualities and what she does to make some of these challenges so much easier for her.

Narayanan (2008) carried out a study, which examined the personality characteristics of 155 individuals between the ages of 20-25 who were categorised as either high or low resilience. The findings suggested that people with high resilience have a tendency to be less impulsive compared to individuals with low resilience. The researcher theorises that when a person is less impulsive, it gives them time to gain control over their emotions.

In a study by Rashid and Gregory (2014), five women were interviewed about their immigrant experiences and their level of resilience. The researchers found connections between specific internal and external protective factors and high resilience. Relevant internal factors were positivity, high self-esteem, sociability, independence, and being good at something. External factors were the support of family and other meaningful people, and the quality of the social environment.

Tugade and Fredrickson (2004) researched the way resilient individuals cope with negative emotional experiences using a three-study multimethod approach. Participants were students at the University of Michigan. Using the Ego-Resiliency Scale, the researchers identified students who had high resilience. They measured the participants' physiological responses in the first two studies, and their responses to a stressful situation in the last study. 
They concluded that people who are resilient use strategies to promote positive emotions to buffer the impact of negative experiences. In essence, they develop their own barrier against the effects of negativity. The only time during her entire immigration experience Cecile admitted to being stressed or frightened in any way was when she was describing the days following defecting from Czechoslovakia, where she feared being caught:

You know, the scary part was the very first days. If I will get out. Okay? If nobody told the ... the authorities that I'm not going to come back, you know, those are things which ... used to be kind of scary I know people who live in...in New York, a friend of mine, yeah? She was turned back from the....from the border. When she tried for the first time to defect.

Cohen (2012) at the University of Minnesota carried out a PhD thesis on the subject of Jewish immigrant women during the Progressive Era (1890s-1920) and their power, resilience, and leadership. The study was an ethnography using feminist theory in the analysis. It was primarily a large-scale historical literature review looking into the qualities and strategies associated with resilience in Jewish immigrant women. Her results uncovered resiliency in these women in the form of the following personality characteristics: persistence, effectiveness, adaptability, courage, determination, and relentlessness. They stood up for themselves, demonstrating real empowerment:

These women did not allow anyone else to have power over their path. Their path lived in the Jewish history of origin and purpose (p.3).

Cohen concluded that these qualities associated with resilience allowed these women to succeed on their assimilation into the new society:

The Jewish women's resiliency, power, and leadership carried them successfully and remarkably into the future (p.3). 
Other research looking into the qualities associated with resilience have found a link with the characteristics of tenacity, flexibility, creativity, sense of humour, optimism, insight and interdependence (Flach, 1988; Mangham, Reid, McGrath, \& Stewart, 1995, Middleton-Moz, 1992; O’Gorman, 1994; Toth, 2003). Several of these qualities, such as sense of humour and flexibility, overlap with characteristics observed in Cecile's personality.

During the analysis, several qualities were identified as contributing to Cecile's resilience. First and foremost, she has high self-esteem and she stands up for herself. She's assertive: she tells people exactly who she is and how she expects to be treated, and she can do it in an unfamiliar language. This is similar to the internal factors of self-esteem and positivity reported by Rashid and Gregory (2014). These qualities were evident when she spoke back to the interviewer who wanted to hire a Canadian student. In another incident she described, a stranger mocked her language skills, and she explained how she had words with the culprit:

This Canadian guy who was working for my brother in law... or ex brother in law...he said, "My English is better than yours." And I looked at him sweetly, and I said, "Billy, you know what? Wait until you will be 40 , then move to another country, with a completely different language, learn the language, and then you can come back to talk to me about my English. And then a couple of weeks later when my sister-in-law came back they fired him. Because he (brother-in-law) said, "Nobody will make fun of me, or you, or our ability to communicate."

There is evidence to support the idea that standing up for your beliefs and saying what you think have a positive psychological effect (University at Buffalo, 2016). One study randomly assigned people to one of four groups where they had to either conform with the group opinion that they either agreed or disagreed with or speak out against it. People who had to conform with an opinion they didn't agree with responded physiologically in a negative way, as if they were being threatened. However, people who had to speak out against the group responded 
physiologically in a positive way, as if they were being challenged (Seery, et al, 2016). The researcher explained that, "you may have to work to reach a goal, but when you experience challenge, it is more like feeling invigorated than overwhelmed. It is consistent with seeing something to gain rather than focusing on what can be lost (University at Buffalo, 2016)." In the study by Rashid and Gregory (2014, p.211), one important finding was that, "acts of resistance reframed their identities and empowered them." When a woman resisted and stood up for what she wanted, it was found to have a positive effect on her mental health. Similarly, when Cecile stood up for herself it empowered her.

In attempting to find a family doctor in Toronto, Cecile initially encountered a barrier. When her sister spoke to her family doctor about taking Cecile on as a patient, the doctor replied that he was not accepting any new patients. When by chance she ended up in that doctor's office with her niece, Cecile managed to change his mind using a similar strategy - by telling him who she is and what she expects. She described how this empowered her and immediately lifted the barrier:

And then one day my oldest niece was sick and my sister didn't have time to go to the doctor. I was still... at home, or whatever, so I just took my niece to the doctor and I was sitting there looking at... at how he was examining her, and he thought - he probably thought I'm some kind of nanny or something, you know? And, a couple of seconds later I said, "Doc, why don't you give her Septeal, or something similar? And he looks at me, and he goes like, “And you are?" and I said, "I'm Adele's sister; I'm her aunt. I'm a pharmacist by profession but I don't have a licence here yet." And he says, "I know that I told your sister I'm not taking new patients, but you're welcome in my office anytime."

In order to analyse which qualities of resilience Cecile used in this context, it's important to look back to Rashid and Gregory (2014) and the internal protective factors they associated with resilience, which included positive temperament, self-esteem, sociability, autonomy, and being good at something (Rashid and Gregory, 2014). It is specifically these qualities in Cecile 
that allow her to question the doctor - particularly her high self-esteem and confidence in her abilities and knowledge as a pharmacist. These domains seem to overlap with four out of the 'big five' personality qualities that represent a well-adjusted person: openness, conscientiousness, extraversion, and agreeableness (Goldberg, 1990).

Another key quality that Cecile possesses is determination. Throughout my interviews with her she stressed that when she has a goal, she never veers from the path either mentally or physically. It is this determination that kept her going throughout her integration process:

Like I said I decided to do it; I bear the consequences. That's it.

Oh, even if there were I just, you know, 'You wanted to do this; you are here; you do it.' Like I said, I decided to go and live in Canada and that was it.

Well, I just accepted that I have to change, so if I don't then why I came here? That's it.

In Cohen's (2012) study of resilience in Jewish immigrant women during the progressive era, determination was one of the key qualities in the women that contributed to their tremendous resilience. The finding here resonates with that finding, for a Jewish immigrant women during the 1980s. One of the findings that Tugade and Frederikson (2004) uncovered in their study was that even when they are under a lot of pressure, people with high resilience feel positive emotions. Determination seems to be an example.

Beyond determination, Cecile has a great, slightly cynical sense of humour, which she brings forth in most situations. She'll laugh that, "Even if I complain who is going to help me?" And she does have the ability to laugh at herself. The role of humour and laughter in positive mental health is well known (Takaoka, 2012).

Before Cecile defected, for example, she visited Toronto and stayed with her sister. Her sister decided to give her a quick course in the essentials of the English language, and she described the lesson during one of the interviews: 
I told you I was '86 in Canada - and when I came my sister said I have to give you a small course in English. Yeah? And I said okay. I didn't think I would understand anything anyway - hi, bye, and garbage. 'Hi' I understand it's like a greeting here, 'bye' it's when you're leaving yeah. But why 'garbage'? What is garbage? Yeah? And she was like, "Everything is garbage!"

When she first got to Canada and she was living at her sister's house, Cecile still hardly knew any English. But rather than give in to that stressful situation, she was able to joke with her sister about it:

My sister...she was in real estate at that time. They were calling her, the colleagues and I don't know what, and she left her youngest at home, and the telephone, yeah? I said what I'm going to do? She said, "Tell them I'm not home." I said, "Okay, but how, what am I going to tell them, yeah?" So it was funny.

Narayanan (2008) has suggested that resilience and certain personality traits, like

sociability, constantly reinforce each other. Someone who can see the positive in almost every situation, and take everything with a sense of humour, has strong resiliency skills.

Cecile even finds humour in the whole area of depression and antidepressant medication. This response is a strength that keeps her mentally healthy, inherent to how she understands the world. At one point she described a conversation she had with her doctor:

I told her, "I was let go at work." So she said, "Do you want antidepressants?" And I said, "No, I said I was let go at work, I didn't say I was depressed." (laughter) She knew I was a pharmacist! You know it is...it's the first on their mind, yeah, antidepressants.

She described her general attitude towards depression with the same unique, cynical sense of humour. She said that she sees depression as an indulgence that an immigrant cannot afford. In essence, she thinks it is a choice:

You know I have a very good friend, she's about 20 years younger than I am, and...she's also a pharmacist, she's from Africa, and she goes like, "I'm depressed." And I said, "Girl, stop it. You cannot afford to be depressed. You aren't rich enough!" (laughter) So this is my attitude towards depression, you know. 
In a review if the literature, Tugade and Fredrickson (2004) concluded that resilient individuals are energetic, curious, open, optimistic, zestful, and very positive. There is some evidence which shows that resilient individuals use humour as a strategy to elicit positive feelings (Werner \& Smith, 1992). Researchers have found that there is a strong link between positive emotions and good mental health, and that the ability to control emotions under stress may be different in different individuals (Tugade and Fredrickson, 2004).

One of Cecile's best qualities when it comes to resilience is her ability to find the right person at the right time to help her in whichever situation she finds herself. At each stage of her journey, there was someone there helping her get to the next stage: her cousin in Germany, for example, her sister, the friend that encouraged her to get her pharmacy license in Canada. This aligns to some extent with Rashid and Gregory's (2014) external factors of 'support of family and other meaningful people' and 'the quality of the social environment'. If nobody appeared, she actively sought them out, like when she went to the registrar at the Ontario College of Pharmacists for help getting a job. It's important to stress here that helping pharmacists to find work is not one of the registrar's responsibilities, but it was an effective strategy on Cecile's part. The ability to ask for help is an important coping strategy. Cecile explained how she felt about asking others for help:

Umm...I would say I'm not afraid to ask for help if I need...even a stranger. Even a stranger many times really helped me. Like the registrar; he really did help. I'm so grateful for that.

Cecile is both very independent and very flexible. Flexibility is a key component of mental health, and is a quality that seems to really assist people to effectively get through the challenges of daily life (Kashdan, 2010). She explained that after university, she was willing to move far from her home to a good job, while her colleagues weren't willing to do so: 
For example when I finished the university, long time ago - okay everyone was looking for job in the city where we were from, yeah? Even the people who weren't from that city, and this is why I couldn't get job there. So I just took off and I applied for a job 100 kilometres away... which is like, in my country, it's across the country.

Cecile was able to start out in Canada in a situation where for eight months she was quite isolated in the suburbs without a car, without the language, and quite dependent on her sister, and she came out of it in good mental health. In contrast, all of the immigrant women in the Rashid and Gregory (2014) study cited loneliness and isolation as their number one source of stress. The inability to speak the language was also a major barrier and frustration, while it didn't seem to bother Cecile (Rashid and Gregory, 2014). She simply found a way around it, like taking an English speaker along on an errand, until she could communicate well enough herself.

When she got her job at the pharmacy, she was quite happy to start out doing deliveries. In certain mental illnesses, the ability to be flexible is damaged or non-existent, so it should not be surprising that it is a feature of good mental health (Kashdan, 2010). This flexible attitude is a primary component of Cecile's resilient qualities. This finding is similar to that of Tugade \& Fredrickson (2004), who found that resilient individuals are able to promote positivity in themselves to mask the effects of negative experiences. Somehow Cecile, and other individuals who possess the same high level of resilience, have learned how to put up a protective shield to buffer the effects of stress. Narayanan (2008) states that, "those high on resilience display dynamic self-renewal when faced with similar stressors" (p. 110).

Part of this ability to mask negative experiences lies in her worldview, which doesn't allow for the inability to control one's emotions. This is very much like the highly resilient participants in the Tugade and Fredrickson (2004) study, who were able to use positive emotions to move away from negativity. Faced with mental illness, Cecile will usually turn it into a joke of 
sorts. She explained that she finds mental illness difficult to understand and empathise with, because it's so far removed from anything she herself has ever experienced:

Even being a healthcare professional I never believed in depression. I just... seeing all those anti-depressants people are taking... and call it 'happy pills.'

When at one point a roommate who was also an immigrant fell into a serious depression, Cecile had trouble taking it seriously or feeling a lot of sympathy for her friend:

Yeah...I don't know what she's doing; I have no idea. But she ... she was whole day in the bed, and you know like - this type of ... depressed people (laughter).

For Cecile, counselling was never something she had never considered. She explained:

Back home it wasn't - I'd say in fashion. Like, you know it's - no, no, you know. I never thought that it's something that is a possibility.

Due to the fact that this was a single-case study, it is not possible to generalise and say that other Jewish women who immigrated to Canada as independent applicants possess the same qualities of resilience. That would require further research. However, because the results on the qualities and factors associated with resilience corresponds with some of the research done in the past on the subject, it does resonate. This study certainly provides insight and reaffirms the research on immigrant resilience, and the body of work on the study of resilience in general. 


\section{Discussion}

The study of resilience is extremely important. Some researchers believe strongly that these skills can be taught. Mangham et al (1995) have suggested that teaching the skills and protective factors associated with resilience would be very valuable in health promotion projects. The health promotion qualities they consider the most important to resilience are, "coping, social support, competence, empowerment, self-esteem, self-efficacy, and self-help" (Mangham et al, 1995, p. 3). They have further proposed that resilience is not a personality trait so much as it is a “process of coping” (Mangham et al, 1995, p.9). Patterson and Keller (2005), in a similar vein, have proposed that resilience is a quality that people develop throughout their lifetimes. With each difficult situation experienced, an individual's resilience grows stronger. If resilience is a learned skill, then perhaps it can be taught, as MacDonnell et al (2012) have suggested. For this reason, it is extremely important to build on the findings of this study with follow-up studies, to further explore the traits or skills associated with resilience in Jewish immigrant women, and in immigrant women in general. As a people, Jews have historically been very nomadic; perpetual immigrants moving from place to place and existing for hundreds of years without a homeland. They have also experienced a tremendous amount of strife over time, and persecution. According to Patterson and Keller's (2005) theory, this suggests that Jewish immigrants in general have already built up a huge amount of resilience from having to deal with trauma and negative experiences.

MacDonnell et al (2012) conducted a study with four focus groups of racialized immigrant women on their resilience and empowerment as it relates to mental health promotion. Their findings revealed that the women displayed considerable resilience in their everyday lives, and that the researchers recommend mental health promotion initiatives to further empower 
racialized immigrant women. Health promotion programs to teach immigrant women coping skills, empowerment and resilience have the potential to make the integration process much easier on many women, as well as have a positive impact on the mental health of immigrant women.

Several health promotion programs for immigrant women exist in Canada which are similar to what MacDonnell (2012) suggested. For example, Costi immigrant services in Toronto runs workshops teaching life skills to immigrant women, including self-esteem and confidence building and communicating assertively. ${ }^{6}$ The Pacific Immigrant Resources Society in Vancouver, B.C. runs the Leadership Education and Development Program (LEAD) for immigrant women. This course includes leadership skills, health and well-being, and interpersonal and communication skills. ${ }^{7}$ Making Changes: Employment and Life Skills Program for Immigrant Women in Alberta has existed since 1979 and it is held at the Arusha International Development Resource Centre in Calgary and the Cross-Cultural Communication Centre in Toronto. The program teaches assertiveness, self-efficacy, career planning, information retrieval, job searches and job maintenance. It was developed to empower immigrant women experiencing social isolation and frustration with the barriers that prevent them from being more socially active and involved, and grew from there based on its success and popularity. ${ }^{8}$

The Canadian mental health policy released by the Mental Health Commission of Canada in 2012 includes a section for immigrants and refugees with five stipulations. Although none of them relates specifically to mental health prevention or health promotion strategies, it does

\footnotetext{
${ }^{6}$ Retrieved from: http://www.costi.org/programs/program details.php?program id=153

${ }^{7}$ Retrieved from: http://pirs.bc.ca/programs-services/womans-development/lead/

${ }^{8}$ Retrieved from: http://www.calgaryunitedway.org/images/uwca/our-work/supporting-non-profits/capacitybuilding/program\%20design\%20example\%20making\%20changes\%20assoc.pdf
} 
prioritize providing immigrant, refugee, ethno-cultural and racialized community organizations with support in assessing local mental health needs along with mental health and other service systems. This stipulation is somewhat general and could suggest health promotion programs or intervention by public health practitioners. George, Thomson, Chaze, \& Guruge (2015) have suggested that, "there is a need for practitioners to intervene at the preventive level to address settlement related stressors" (p. 13634).

The findings of this study suggest that the qualities discussed in this MRP are associated with resilience. In the case of Cecile, she was either born with or developed these qualities over time and with experience. It's clear that they serve as protective factors, preventing her from developing mental health issues. The first quality is independence, including the ability to immigrate independently. The ability to ask others for help, whether it's friends or strangers, is another key factor in Cecile's resiliency. It helps move her forward in overcoming obstacles. Her sense of humour helps her to lighten her stress and it's possible that it serves a bit of a distancing function as well, and that she uses humour and laughter to bounce back from negative emotional experiences as Tugade and Fredrickson (2004) have discussed. Cecile has a fierce determination to follow through with any goal she has set, which is another resiliency factor. Finally, she has the psychological flexibility to withstand difficult or uncomfortable situations, knowing the situation will improve over time. Teaching these skills may have an impact on immigrant women's' mental health, and make their integration process much easier, as many programs have already done. Jewish immigrant women would certainly benefit mental health-wise from developing and working on these qualities. 


\section{Conclusion}

Further research is needed to understand whether other immigrant women who have immigrated to Canada as independent applicants, Jewish or not, share the same qualities and resilience. Follow-up research should explore the issue of resilience in other Jewish immigrant women who have immigrated to Canada independently.

The most important results of this study were the insights about resilience, and the qualities associated with resilience for Cecile. Some of these qualities align with past findings about the personality traits associated with this quality. As Mangham et al (1995) suggested, resilience really is not a personality trait but a coping strategy, which is composed of a number of qualities. Cecile herself admitted she was much more able to take care of herself after several years here, compared to before she immigrated to Canada. An individual can build up resilience over time, gaining confidence with each difficult situation. This is an area that deserves more careful attention in both research and in health promotion. 


\section{Appendices}

\section{Appendix A - Collecting Personal Data}

Please complete the following personal data. This data will never be associated with your name, as a pseudonym will be used. It will be kept in my computer (Melissa Feldman), which is locked with a password. I am the only person who will have access to this information. This form will be kept for five years locked in Sepali Guruge's cabinet in the university, and will then be destroyed.

\begin{tabular}{|l|l|}
\hline Name & Cecile \\
\hline Age at Immigration & \\
\hline Length of Time in Canada & \\
\hline Current Age & \\
\hline Highest Level of Education & \\
\hline Profession & \\
\hline Current Marital Status & \\
\hline Marital Status at Immigration & \\
\hline
\end{tabular}




\section{Appendix B - Interview Guide: Researching the Mental Health of a Jewish Immigrant Woman}

Thank you very much for taking part in my research study. My name is Melissa, and I'm a Masters student at Ryerson University.

My background also involves an immigrant experience. When I was 26, I immigrated to Israel alone and stayed for 18 years. I'm very familiar with the ups and downs of immigration, and the difficulty of learning a new language and culture. Your experience of coming from your country to Canada and building a new life here may be different.

The interview today will take approximately one hour. The details of this discussion will be kept completely confidential. The only people who will have access to the interview will be myself and my research supervisor, Dr. Sepali Guruge. I will remove any identifying information from your transcript and use a pseudonym. You may change your mind and back out of the interview or remove your data at any point, including after the interview is over.

Before we start the interview, do you have any questions? If you have no questions, let's begin.

\section{Interview 1}

1. What are the details of your immigration? (when, where, how?)

2. What have been the biggest difficulties or challenges of your immigration and settlement?

3. How did these difficulties or challenges affect you - in particular your mental health?

4. Which difficulty or challenge had the biggest effect on you, and why?

5. Which services, i.e. counselling/mental health treatment did you use?

6. What was your experience of those services?

7. If you have not used mental health services, what prevented you from seeking them out?

8. What changes would you like to see in these services? 


\section{Interview 2}

1. Were you friends with any other single Jewish immigrant women as a new immigrant? If so, what were the similarities and differences in how you dealt with your experiences?

2. Did you reach out to your cultural community at the start of your immigration? How did this affect your experience?

3. How did it impact your life to not be able to do familiar things easily and/or without help at the beginning of your immigration (shop, sign contracts, banking, etc)?

4. What were the most frustrating situations where you didn't know enough English?

5. What aspect of Canadian culture was most difficult for you to adopt and why?

6. There's a Czech proverb that says, "Learn a new language and get a new soul." What do you think?

7. What about life in your home country did you miss in your first few years here?

8. If you had come here with a spouse, how would that have changed your experience?

9. Was there anything related to being a woman that affected your immigrant experience?

10. What qualities in yourself do you think led to a successful immigration and integration? Please elaborate.

\section{Interview 3}

1. How did the challenges in your immigration change the way you see yourself, in the short or long term?

2. Successfully immigrating to a country as a single woman takes a lot of resilience. Resilience is the ability to recover from difficulty easily. How did you develop your resilience?

3. What do you tell yourself when you come across a barrier (like not finding work)? How do you decide on your next move or solution? 
4. Let's say something negative happens to you where you are heavily criticised. For example, you're fired from a job as a pharmacist and the boss tells you that you are terrible at what you do. Think of an example/s. How do you feel? Describe how you would react to such a situation and what your next steps would be.

5. You have just had a generally bad day at work and out in the world. How do you relax? What do you do to move on from the bad day, and from negative thoughts?

6. What advice would you give a single 40 year old woman from your country who was about to immigrate to Canada? What about after she arrives?

7. What is the best advice that you got about your immigration?

Concluding: Thank you very much for your participation in my study. 


\section{Appendix C - Counselling Information and Resources}

\section{Counselling}

519 Church Street Community Centre 416-392-6874

Clinic for Person Centered Psychotherapy 416-229-2399

East Toronto Health Centre 416-778-1496

Psychotherapy and Counselling Centre 416-516-6969

Sunnybrook Psychotherapy for Women 416-591-2000

Toronto General-Women's Mental Health Clinic 416-340-3048

Woodgreen Walk-In Counseling 416-645-6000 x 2512

\section{Jewish Family and Child}

Jewish Family \& Child offers programs and services for couples, families and individuals of every age, social and economic background. JF\&CS is the Children's Aid Society for the Jewish community in the GTA and York Region. JF\&CS offers support, services and counselling related to: poverty and employment rehabilitation; woman abuse; child welfare; marital and family issues; and chaplaincy.

4600 Bathurst Street, 1st \& 2nd Floor, Toronto, ON M2R 3V2

P: (416) 638-7800

info@jfandcs.com

http://www.jfandes.com

\section{Other Locations:}

- Gordon S. Wolfe Branch: 35 Madison Avenue, Toronto| Tel. (416) 961-9344

- Joseph \& Wolf Lebovic Jewish Community Campus 9600 Bathurst Street, Suite 242, Vaughan, Ontario. Tel. (905) 303-5838

\section{Hotlines}

- Mental Health Crisis Line: 1-888-893-8333

- $\quad$ Suicide and Crisis Hotline (Canada-wide): 1-800-448-3000

- Distress line: 416-408-4357

- $\quad$ Gerstein Crisis Centre (Downtown): 416-408-4357 


\section{Appendix D: Flyer for Recruitment}

\section{JEWISH IMMIGRANT WOMAN NEEDED for Research Study}

My name is Melissa Feldman, and I'm a student at Ryerson University. I am a Canadian Jewish woman who immigrated to Israel in 1996 and lived there for 18 years, returning to Canada three years ago. I am conducting a research study in partial fulfillment of the degree of Masters of Arts in Immigration and Settlement Studies. The study aims to understand Jewish women who have immigrated to Canada, and their experiences.

- I am looking for a Jewish woman over the age of 18 who immigrated to Canada independently as a principal applicant in the economic class. To participate, you must also have been in the country for at least five years, were single when you arrived in Canada and speak English fluently.

- The one hour interviews will take place either at Ryerson University, in an interview room in a building at Yonge and Eglinton or in a quiet café /other location of your choice.

- You will be asked to share experiences as an immigrant woman in Canada.

- The goal is to bring awareness to issues relevant to Jewish immigrant women.

- A $\$ 30$ incentive will be given.

Any information you share in this study will be kept in the strictest of confidence. If you are interested in participating in this study, please contact me at: $\underline{\text { melissa.feldman@ryerson.ca }}$

REB\#: 2017-138 


\section{Appendix E: Phone/in person Scripts for Recruitment of Jewish Woman}

My name is Melissa Feldman, and I'm a student at Ryerson University. I'm conducting a research study in partial fulfillment of the degree of Masters of Arts in Immigration and Settlement Studies. For the study, I will be interviewing a Jewish woman above the age of 18 who immigrated to Canada independently under the economic criteria. There will be 3 interviews. The interviews will take place either at Ryerson University, in an interview room in a building at Yonge and Eglinton or in a quiet café /other location of your choice.

To participate, you must have immigrated to Canada as a principal applicant in the economic class, have been in the country at least five years, were single when you arrived in Canada and speak English fluently.

The goal of this research is to bring awareness to issues pertinent to Jewish immigrant women. Are you interested in participating or helping me find a woman to interview? 


\section{Appendix F: Email Script for Recruitment of Jewish Woman}

Hello,

My name is Melissa Feldman, and I am a student at Ryerson University. I am conducting a research study in partial fulfillment of the degree of Masters of Arts in Immigration and Settlement Studies. For the study, I will be interviewing a Jewish woman over the age of 18 who immigrated to Canada independently under the economic criteria. There will be 3 interviews. The interviews will take place at Ryerson University, in an interview room in a building at Yonge and Eglinton or in a quiet café /location of your choice.

To participate, you must have immigrated to Canada as a principal applicant in the economic class, have been in the country at least five years, were single when you arrived in Canada and speak English fluently.

The goal of this research is to bring awareness to issues pertinent to Jewish immigrant women. Are you interested in participating or helping me find a woman to interview?

I have attached the consent form for your review. Should you be interested I can be reached at 647-546-8584 or at melissa.feldman@ @ryerson.ca

Best regards,

Melissa Feldman 


\section{Appendix G: Checklist to Improve Trustworthiness of a Case Study Report}

(Stake, 1995)

1. Is this report easy to read?

2. Does it fit together, each sentence contributing to the whole?

3. Does the report have a conceptual structure (i.e. themes or issues?)

4. Are its issues developed in a serious and scholarly way?

5. Is the case adequately defined?

6 . Is there a sense of story to the presentation?

7. Is the reader provided some vicarious experience?

8. Have quotations been used effectively?

9. Are headings, figures, artefacts, appendices and indexes effectively used?

10. Was it edited well, then again with a last minute polish?

11. Has the writer made sound assertions, neither over- nor under- interpreting?

12. Has adequate attention been paid to various contexts?

13. Were sufficient raw data presented?

14. Were data sources well-chosen and in sufficient number?

15. Do observations and interpretations appear to have been triangulated?

16. Is the role and point of view of the researcher nicely apparent?

17. Is the nature of the intended audience apparent?

18. Is empathy shown for all sides?

19. Are personal intentions examined?

20. Does it appear individuals were put at risk? 


\section{Appendix H: Consent Form for Jewish Immigrant Woman}

\section{Ryerson}

University

\section{Ryerson University Consent Agreement: Jewish Immigrant Woman}

You are being invited to participate in a research study. Please read this consent form so that you understand what your participation will involve.

Before you consent to participate, please ask any questions to be sure you understand what your participation will involve.

For this study, I am looking for a Jewish woman over the age of 18 who immigrated to Canada independently as a principal applicant in the economic class. To participate, you must also have been in the country at least five years, were single when you arrived in Canada and speak English fluently. You may not participate if you were born in Israel, male, a Canadian native, non-Jewish, under 18, don't speak English fluently, arrived in Canada under the family class or as a refugee, were married at the time of immigration or if you have been in the country less than five years.

\section{Mental Health of a Jewish Woman who Immigrated to Canada as an Independent Applicant}

\section{INVESTIGATORS:}

This research study is being conducted by Melissa Feldman and Dr. Sepali Guruge from the Immigration and Settlement Studies and Nursing Departments at Ryerson University. If you have any questions or concerns about the research, please feel free to contact Melissa Feldman or Dr. Sepali Guruge at melissa.feldman@ @ryerson.ca or sguruge@ ryerson.ca

\section{PURPOSE OF THE STUDY:}

The purpose of this study is to talk to a Jewish immigrant woman about her immigration experiences. We especially want to find out about the impact of immigration on mental health.

As a graduate student, this study will contribute to my Major Research Paper (MRP) and the final document will be reviewed by my supervisor, Dr. Sepali Guruge, and a second reader. It will be available online via the Ryerson library catalogue search. There is a possibility that it will be presented at a scientific conference or published in a journal in the future.

\section{WHAT PARTICIPATION MEANS:}

If you volunteer to participate in this study, you will be asked to meet for three 45-minute interviews with the researcher. She is a Jewish woman who was also an immigrant. You will talk about your immigrant experience and how it affected you. The interview location will be either at Ryerson University, in an interview room in a building at Yonge and Eglinton or in a quiet café /other location of your choice. The results of the research will not be made generally available. However, I will send out a short summary to the participant in the fall.

Sample Interview Questions: 
1. What have been the biggest difficulties or challenges of your immigration and settlement?

2. How did these difficulties or challenges affect you - in particular your mental health?

\section{POTENTIAL BENEFITS:}

There is no guarantee that participants will benefit by participating. However, this research gives you a chance to tell your story, which may help build knowledge about Jewish immigrant women and mental health.

\section{WHAT ARE THE POTENTIAL RISKS TO YOU AS A PARTICIPANT?}

There are very few risks involved in participating in this study. However, you may become sad or uncomfortable talking about emotions. You can stop the interview at any time, either for a break or completely. I can also provide you with contact information of agencies and services that may be of use to you to get help for your concerns.

\section{CONFIDENTIALITY:}

Participation in the study is voluntary. Care will be taken to make sure that any names or identifying information are removed from the transcriptions.

You will have the right to review the printed transcripts, and make editing changes if you wish. This would be to make sure the interview was transcribed correctly or to check if there is anything you want removed. Pseudonyms will be used in reporting the results of the study.

All of the recordings will be kept on a secure database which is password protected, and the hard copies of consent forms will be kept in a locked cabinet in Dr. Sepali Guruge's office at Ryerson University. USB sticks will not be used unless the data has been encrypted.

The raw data will be deleted at the end of the study, but the transcripts will be kept locked in Sepali Guruge's cabinet for five years incase of a follow up study. If you should wish to withdraw from the study at any time before or after your interview, your data will be shredded and all files and emails will be deleted.

\section{COSTS TO PARTICIPATION:}

There are no direct costs associated with participating in this study, with the exception of transportation. You will be given a $\$ 30$ incentive for your participation in the study. This incentive will be given to you even if you decide not to complete the interview.

\section{COMPENSATION FOR INJURY:}

By agreeing to participate in this research, you are not giving up or waiving any legal right in the event that you are harmed during the research.

VOLUNTARY PARTICIPATION AND WITHDRAWAL: 
Participation in this study is completely voluntary. You can choose whether to be in this study or not. If any interview question makes you uncomfortable, you can skip that question. You may stop the interview at any time and you will still be given the incentive described. If you choose to stop participating, you may also choose to not have your data included in the study. You can even do this after the interview is over. Your choice of whether or not to participate will not influence your future relations with Ryerson University or the investigators, Melissa Feldman and Dr. Sepali Guruge, involved in the research.

\section{QUESTIONS ABOUT THE STUDY:}

If you have any questions about the research now, please ask. If you have questions later about the research, you may contact:

Melissa Feldman, MA student, Ryerson University

Ryerson University

350 Victoria Street

Toronto, ON M5B 2K3

melissa.feldman@ryerson.ca

416-979-5000 ext. 4964

Dr. Sepali Guruge, Professor; Daphne Cockwell School of Nursing Research Chair in Urban Health

Ryerson University

350 Victoria Street

Toronto, ON M5B 2K3

sguruge@ ryerson.ca

416-979-5000 ext. 4964

This study has been reviewed by the Ryerson University Research Ethics Board. If you have questions regarding your rights as a participant in this study please contact:

Research Ethics Board c/o Office of the Vice President, Research and Innovation

Ryerson University

350 Victoria Street

Toronto, ON M5B 2K3

416-979-5042

rebchair@ryerson.ca 
Research Project: Of Resilience and Empowerment: Mental Health of a Jewish Woman who Immigrated to Canada as an Independent Applicant

\section{CONFIRMATION OF AGREEMENT:}

Your signature below indicates that you have read the information in this agreement and have had a chance to ask any questions you have about the study. Your signature also indicates that you agree to participate in the study and have been told that you can change your mind and withdraw your consent to participate at any time. You have been given a copy of this agreement.

You have been told that by signing this consent agreement you are not giving up any of your legal rights.

Name of Participant (please print)

Signature of Participant

Date

I agree to be audio-recorded for the purposes of this study. I understand how these recordings will be stored and destroyed.

Signature of Participant

Date

I would like to review my transcript before it is included in the researcher's Major Research Paper.

I would like to be contacted again for a second and third interview. 


\section{Bibliography}

Ballantyne, M., Benzies K.M., Trute, B. (2013). Depressive symptoms among immigrant and Canadian born mothers of preterm infants at neonatal intensive care discharge: a crosssectional study. BMC Pregnancy and Childbirth, 13:1, pp. 1-10.

Banerjee, R. \& Phan, Mai B. (2015). Do Tied Movers Get Tied Down? The Occupational Displacement of Dependent Applicant Immigrants in Canada. Int. Migration \& Integration, 16, pp. 333-353.

Baxter, P. and Jack, S. (December 2008). Qualitative Case Study Methodology: Study Design and Implementation for Novice Researchers. The Qualitative Report, 13:4, pp. 544-559.

Bonner, A \& Tolhurst, Gerda (2002). Insider-outsider perspectives of participant observation. Nurse Researcher, 9:4, pp. 7-19.

Cantor-Graae E, Selten J-P. (2005). Schizophrenia and migration: a meta-analysis and review. Am J Psychiatry, 162, pp. 12-24.

Centre for Disease Control (2016). Mental Illness. Retrieved from: http://www.cdc.gov/mentalhealth/basics/mental-illness.htm

Chen, A.W., Kazanjian, A. \& Wong, H. (December 2008). Determinants of Mental Health Consultations Among Recent Chinese Immigrants in British Columbia, Canada: Implications for Mental Health Risk and Access to Services. Journal of Immigrant and Minority Health, 10:6, pp. 529-540.

Chui, Tina. Immigrant Women. Statistics Canada. Retrieved from: http://www.statcan.gc.ca/

Canadian International Jewish Appeal: CIJA (2015). Brief History of Canadian Jewry. Retrieved from: http://www.cija.ca/resource/canadian-jewry/ 
Citizens for Mental Health (April, 2003). Immigrant and Refugee Mental Health. Canadian Mental Health Association.

Cohen, A.J. (2012). Women's Resiliency, Power and Leadership: a Study of Jewish Immigrant Women of the Progressive Era (PhD thesis). University of St. Thomas, Minnesota, pp. 1233.

Collins Dictionary (2016). Immigrant. Harper Collins Publishers Ltd. Retrieved from: https://www.collinsdictionary.com/dictionary/english/immigrant

Galletta, A. (June 2013). Mastering the Semi-Structured Interview and Beyond: From Research Design to Analysis to Publication. New York Press. Retrieved from: http://www.jstor.org/stable/j.ctt9qgh5x

Crowe, S., Cresswell, K., Robertson, A., Huby, G., Avery, A., Sheikh, A. (2011). The case study approach. BMC Medical Research Methodology, 11:100, pp.1-9.

Dean, J \& Wilson, K (2009). 'Education? It is irrelevant to my job now. It makes me very depressed ...': exploring the health impacts of under/unemployment among highly skilled recent immigrants in Canada. Ethnicity \& Health, 14:2, pp. 185-204.

Doenyas, Alon Jonathan (February, 2016). The Transnational Identity of Israeli Immigrants in the United States of America and Canada as a Result of Their Connections with the Local Jewish Communities (unpublished MA thesis). The University at Buffalo, State University of New York. 
Elo, Satu, Kaariainen, Maria, Kanste, Outi, Polkki, Tarja, Utriainen, Kati, \& Kyngas, Helvi (2014). Qualitative Content Analysis: A Focus on Trustworthiness. Sage Publishing, pp. 1-10.

Flach, F. (1988). Resilience: Discovering a new strength at times of stress. New York: Fawcett Columbine.

Gabriel, Christina (2006). A Question of Skills: Gender, Migration Policy and the Global Political Economy. In Kees van der Pijl, Libby Assassi and Duncan Wigen (Eds.) Global Regulation: Managing Crises after the Imperial Turn. Palgrave Macmillan, pp. 162-176.

George, U., Thompson, M. S., Chaze, F., \& Guruge, S. (2015). Immigrant mental health, a public health issue: Looking back and moving forward. International Journal of Environmental Research and Public Health, 12(10), pp. 13624-13648. Retrieved from http://ezproFThompsopnxy.lib.ryerson.ca/login?url=http://search.proquest.com/docview/ $\underline{1733897622 ? \text { accountid }=13631}$

Girard, Erik R. \& Bauder, Harold (2007). Assimilation and Exclusion of Foreign Trained Engineers in Canada: Inside a Professional Regulatory Organization. Antipode, 39:1, pp. 35-53.

Goldberg, L.R. (1990). An Alternative 'Description of Personality': The Big Five Factor Structure. Journal of Personality and Social Psychologs, 59:6, pp. 1216-1229

Greene, M.A., Evans, C.R. \& Subramanian, S.V. (2017) Can intersectionality theory enhance population health research? Social Science and Medicine, 178, pp. 214-216. 
Guo, Shiboa (November, 2009). Difference, Deficiency and Devaluation: Tracing the Roots of Non-recognition of Foreign Credentials for Immigrant Professionals in Canada. The Canadian Journal for the Study of Adult Education 22:1, pp. 37-49.

Guruge, S., and Collins, E. (2008). Emerging Trends in Canadian Immigration and Challenges for Newcomers. In, Guruge, S. and Collins, E. (Eds). (2008). Working with Immigrant Women: Issues and Strategies for Mental Health Professionals. Canada: Centre for Addiction and Mental Health.

Guruge, S., Collins, E. \& Bender, A. (2010). Working with Immigrant Women: Guidelines for Mental Health Professionals. Canadian Issues, pp. 114-124. Retrieved from: http://canada.metropolis.net/pdfs/immi_health/Immigrant\%20Mental\%20Health\%20\%20pgs114-124.pdf

Guruge, S., Thompson, M.S. \& Seifi, S.G. (2010). Mental Health and Service Issues Faced by Older Immigrants in Canada: A Scoping Review. Canadian Journal on Aging, 34(4), pp. $431-444$.

Guruge, S., Thompson, M.S., Usha, G. \& Chase, F. (2015). Social Support, Social Conflict, and Immigrant Women's Mental Health in a Canadian Context: A Scoping Review. Journal of Psychiatric and Mental Health Nursing, 22, pp. 655-667.

Guruge, S., Wang, A. Z. Y., Jayasuriya-Illesinghe, V., \& Sidani, S. (2017; 2016). Knowing so much, yet knowing so little: A scoping review of interventions that address the stigma of mental illness in the Canadian context. Psychology, Health \& Medicine, 22(5), pp. 50717. 
Harris, Brent Davis (2015). Beyond Guilt and Stigma: Changing Attitudes among Israeli Migrants in Canada. International Migration, 53:6, pp. 41-56.

Harrison, H., Birks, M., Franklin, R. and Mills, J. (January, 2017). Case Study Research: Foundations and Methodological Orientations. Forum of Qualitative Social Research, 18:1, 19. Retrieved from http://www.qualitativeresearch.net/index.php/fqs/article/view/2655/4079\#g1

Hyman, Paula (1991). Gender and the Immigrant Jewish Experience in the United States. In Judith Baskin, ed., Jewish Women in Historical Perspective. Detroit, pp. 222-239. Retrieved from: http://faculty.history.umd.edu/BCooperman/NewCity/Jewishwomen.html

Hyman, Paula. Eastern European Immigrants in the United States (2009). Jewish Women: A Comprehensive Historical Encyclopedia. Jewish Women's Archive. Retrieved from: https://jwa.org/encyclopedia/article/eastern-european-immigrants-in-united-states

Kashdan, T. B. (November 2010). Psychological Flexibility as a Fundamental Aspect of Health. Clin Psychol Rev, 30(7), pp. 865-878.

Kelley, N. and Trebilcock, M. The Making of the Mosaic: A History of Canadian Immigration Policy (2nd edition). University of Toronto Press (2013).

Khanlou, N. (March 2009). Immigration mental health policy brief prepared at the request of the Public Health Agency of Canada and Metropolis Canada, Ottawa.

Khanlou, N. (2010). Migrant Mental Health in Canada. Canadian Issues: Immigrant Mental Health, Public Health Agency of Canada, pp. 9-14. 
Khanlou, N., Haque, N., Sheehan, S., \& Jones, G. (2015). "It is an issue of not knowing where to go": Service providers' perspectives on challenges in accessing social support and services by immigrant mothers of children with disabilities. Journal of Immigrant and Minority Health, 17(6), pp. 1840-1847.

Khanlou, N., Haque, N., Mustafa, N., Vazquez, L. M., Mantini, A., \& Weiss, J. (2017). Access barriers to services by immigrant mothers of children with autism in Canada. International Journal of Mental Health and Addiction, 15(2), pp. 239-259.

Kirmayer, L.J. MD, Narasiah, Lavanya MD MSc, Munoz, Marie MD, Rashid, Meb MD, Ryder, Andrew G. PhD, Guzder, Jaswant MD, Hassan, Ghayda PhD, Rousseau, Cécile MD MSc, Pottie, Kevin MD MClSc; for the Canadian Collaboration for Immigrant and Refugee Health (CCIRH) (2011). Common mental health problems in immigrants and refugees: general approach in primary care. Canadian Medical Association Journal 183(12), pp. 959-965.

Koehn, S., Neysmith, S., Kobayashi, K., \& Khamisa, H. (2012; 2013). Revealing the shape of knowledge using an intersectionality lens: Results of a scoping review on the health and health care of ethnocultural minority older adults. Ageing and Society, 33(3), pp. 1-28.

Kohn, L.T. (June 1997). Methods in Case Study Analysis. The Center for Studying Health System Change, Technical Publication, 2, pp. 1-8.

Koffman, David \& Weinfeld, M (2011). Recent Developments in the Social Scientific Study of Canadian Jews. Cont Jewry, 31, pp. 199-221. 
Lai, Yvonne \& Hynie, Michaela (2010). Community Engagement and Well-Being of Immigrants: The Role of Knowledge. Canadian Issues: Immigrant Mental Health, Public Health Agency of Canada, pp. 93-96.

MacDonnell, J.A., Dastjerdi, M., Bokore, N., \& Khanlou, N. (2012). Becoming Resilient: Promoting the Mental Health and Well-Being of Immigrant Women in a Canadian Context. Hindawi Publishing Corporation, Nursing Research and Practice, V2012, pp. 110.

Mangham, C., McGrath, P., Reid, G., \& Stewart, M. (1995). Resiliency: Relevance to health promotion. Detailed analysis. Halifax: Atlantic Health Promotion Research Centre, Dalhousie University, Canada.

Med library.org. History of the Jews in Canada. Retrieved from:

http://medlibrary.org/medwiki/History_of_the_Jews_in_Canada

Mental Health Commission of Canada. (2012). Changing directions, changing lives: The mental health strategy for Canada. Calgary, AB.

Middleton-Moz, J. (1992). Will to survive: Affirming the positive power of the human spirit. Deerfield Beach, FL: Health Communications, Inc.

Na, S., Ryder, A.G., \& Kirmayer, L. (September 2016). Toward a Culturally Responsible Model of Mental Health Literacy: Facilitating Help-Seeking Among East Asian Immigrants to North America. American Journal of Community Psychology, 58:1-2, pp. 211-225.

Narayanan, A. (April 2008). The Resilient Individual: A Personality Analysis. Journal of the Indian Academy of Applied Psychology, 34, pp.110-118. 
Ng, Edward \& Omariba, Walter (2010). Is there a Healthy Immigrant Effect in Mental Health?

Evidences from Population-based Health Surveys in Canada. Canadian Issues: Immigrant Mental Health, Public Health Agency of Canada, pp. 23-27.

O'Gorman, P. (1994). Dancing backwards in high heels: How women master the art of resilience. Center City, MN: Hazelden Educational Materials.

O’Mahony J.M., Donnelly T.T., Bouchal S.R., et al. (2013) Cultural background and socioeconomic influence of immigrant and refugee women coping with postpartum depression. Journal of Immigrant and Minority Health 15, pp. 300-314.

Patterson, J.L., \& Kelleher, P. (2005). A deeper meaning of resilience. In Resilient school leaders: Strategies for turning adversity into achievement, eds. Jerry L. Patterson and Paul Kelleher, Alexandria, VA: Association for Supervision and Curriculum Development, pp.1-18.

Phoenix, A. \& Pattynama, P. (2006). Editorial: Intersectionality. European Journal of Women's Studies, SAGE Publications, 13(3), pp. 187-192.

Rashid, R. \& Gregory, D. (2014). 'Not Giving Up on Life’: A Holistic Exploration of Resilience among a Sample of Immigrant Canadian Women. Canadian Ethnic Studies, 46:1, pp.197214.

Robert, Anne-Marie \& Gilkinson, Tara (November 2012). Executive Summary: Mental health and well-being of recent immigrants in Canada: Evidence from the Longitudinal Survey of Immigrants to Canada. Citizenship and Immigration Canada.

Robinson, Ira (Fall 2009). The Field of Canadian Jewish Studies and Its Importance for the Jewish Community of Canada. Jewish Political Studies Review, 23(3), pp. 75-86. 
Schnoor, Randal F. (2011). The Contours of Canadian Jewish Life. Cont Jewry, 31, pp. 179-197.

Takaoka, S. (2012). Humor Production and Mental Health in Interpersonal Stressful Situations. European Psychiatry, 27:1, p.1. Summary retrieved from: http://www.sciencedirect.com.ezproxy.lib.ryerson.ca/science/article/pii/S0924933812755 712?via\%3Dihub

The Centre for Israel and Jewish Affairs (2011) Retrieved from http://www.cija.ca/resource/canadian-jewry/basic-demographics-of-the-canadian-jewishcommunity/\#

Seery, M.D., Gabriel, S., Shannon P. Lupien, S.P., \& Shimizu, M. (2016). Alone against the group: A unanimously disagreeing group leads to conformity, but cardiovascular threat depends on one's goals. Psychophysiology, 53 (8).

Stake, R. (1995). The Art of Case Study Research. Thousand Oaks, CA: Sage Publications.

Stewart D.E., Gagnon A.J., Merry L.A., et al. (2012) Stewart D.E., Gagnon A.J., Merry L.A. (2012) Risk factors and health profiles of recent migrant women who experienced violence associated with pregnancy. Journal of Women's Health, 21, pp. 1100-1106.

Stewart, M., Reid, G \& Mangham, C. (February1997). Fostering Children's Resilience. Journal of Pediatric Nursing, 12:1, pp. 21-31.

Thompson, Mary Susan, Chaze, Ferzana, George, Usha \& Guruge, Sepali. (2015). Improving Immigrant Populations' Access to Mental Health Services in Canada: A Review of Barriers and Recommendations. J Immigrant Minority Health, 17, pp. 1895-1905. 
Tieu, Y. \& Konnert, C. Mental health help-seeking attitudes, utilization, and intentions among older Chinese immigrants in Canada. Aging \& Mental Health, 18(2), pp. 140-147.

Toth, J.S. (August 2003). Resilience: The Experience of Immigrant and Refugee Women. Master's Thesis. University of Winnipeg: Winnipeg, Manitoba.

Tugade, M. \& Fredrickson, B. (2004). Resilient Individuals Use Positive Emotions to Bounce Back From Negative Emotional Experiences. Journal of Personality and Social Psychology, 86:2, pp. 320-333.

University at Buffalo. (2016, August 19). Standing up for beliefs in face of group opposition is worth the effort, study shows. Science Daily. Retrieved July 19, 2017 from www.sciencedaily.com/releases/2016/08/160819162352.htm

Vigod S., Sultana A., Fung K., Hussain-Shamsy N., Dennis C.L. (2016). A population-based study of postpartum mental health service use by immigrant women in Ontario, Canada. Can J Psychiatry 61(11), pp. 705-713.

Viruell-Fuentes, E.A, M., Patricia, Y., \& Abdulrahim, S. (2012). Review: More than culture: Structural racism, intersectionality theory, and immigrant health. Social Science \& Medicine, 75, pp. 2099-2106.

Werner, E., \& Smith, R.S. (1992). Overcoming the Odds: High Risk Children from Birth to Adulthood. Ithica, NY: Cornell University.

World Health Organisation (2014). Mental health: a state of well-being. Retrieved from: http://www.who.int/features/factfiles/mental_health/en/ 
Yan, Shanshan, (2014). Through an Intersectionality Lens: Service Provider Views on the Sexual Health Needs of Racialized LGBTQ Youth in Toronto. Theses and Dissertations (Comprehensive). 1643.

Yang, L. H., Lai, G. Y., Tu, M., Luo, M., Wonpat-Borja, A., Jackson, V. W, Dixon, L. (2014). A brief anti-stigma intervention for Chinese immigrant caregivers of individuals with psychosis: Adaptation and initial findings. Transcultural Psychiatry, 51(2), pp. 139-157.

Yin, R.K. (2003). Applications of Case Study Research, $2^{\text {nd }}$ Edition. Thousand Oaks, California: Sage Publications.

Zainal, Z. (2007). Case study as a research method. Jurnal Kemanusiaan, 9, pp. 1-6. 